The Abolition of the Slave Trade

\title{
A abolição do tráfico de escravos no Atlântico Sul: Portugal, o Brasil e a questão do contrabando de africanos
}

in the South Atlantic: Portugal,

Brazil and the Issue of the

Smuggling of Africans

\author{
Gilberto da Silva Guizelin \\ Doutorando em História pela \\ Universidade Estadual Paulista \\ (FCHS/UNESP - Franca/Brasil) e \\ bolsista da Fundação de Amparo \\ à Pesquisa do Estado de São Paulo \\ (FAPESP). \\ e-mail: guizelin.gs@gmail.com
}

\begin{abstract}
Resumo
Este artigo aborda a temática da abolição do tráfico de escravos realizado no Atlântico Sul. Cumpre destacar que o estudo que aqui se apresenta não traz uma discussão a partir do enquadramento das relações diplomáticas anglo-brasileiras com a questão do tráfico de escravos, mas sim com base no condicionamento do relacionamento luso-brasileiro com esta questão em meados do século XIX.
\end{abstract}

\begin{abstract}
This article deals with the issue of the abolition of the slave trade in the South Atlantic. It is important to say that this study does not deal with this discussion from the exclusive framework of the diplomatic relations between Great Britain and Brazil regarding the question of slave trade, it is also based on the traditional relations developed between Portugal and Brazil in respect to that same question in the mid-nineteenth century.
\end{abstract}

Palavras-chave

tráfico escravo, diplomacia do tráfico, Portugal, Brasil

Keywords

slave trade, slave trade diplomacy, Portugal, Brazil 
1

0 termo "Mundo Atlântico" aqui utilizado compreende uma modalidade de escrita da História centrada na historicização dos fatos, fenômenos e personagens pertencentes, atuantes e circunscritos ao universo do oceano Atlântico. Nesta perspectiva analítica, a temática do comércio escravista intercontinental - ou, a temática da diáspora, como alguns preferem denominar - tem sido a grande privilegiada dos esforços investigativos com o fito de localizar, debruçar e trazer à luz experiências e interconexões de gentes, episódios e fenômenos até então pouco valorizados ou, mesmo, pouco conhecidos, encerrados e compartilhados entre as diversas sociedades margeadas pelo Atlântico. Para uma leitura mais teórica do termo ver: THORTON, John Kelly. A África e os africanos na formação do mundo atlântico, 1400-1800. Rio de Janeiro: Elsevier/Editora Campus, 2004. p.41-43. Já para uma leitura especificamente voltada para o desenvolvimento desta perspectiva de estudo no cenário historiográfico brasileiro dos últimos anos ver: MAMIGONIAN, Beatriz Gallotti. A África no Brasil: mapa de uma área em expansão. Topoi, Rio de Janeiro, v.5, n.9, p.33-53, 2004

2

Para um estudo amplo e pormenorizado das redes sociais, políticas e mercantis forjadas no seio das sociedades portuguesa e brasileira pelo tráfico atlântico de escravos ver: FRAGOSO, João (Org.). $O$ antigo regime nos trópicos: A dinâmica imperial portuguesa (Séculos XVI-XVIII). Rio de Janeiro: Civilização Brasileira, 2001. FRAGOSO, João; FLORENTINO, Manolo; SAMPAIO, Antonio Carlos Juca; CAMPOS, Adriana Pereira. Nas rotas do império: Eixos mercantis, tráfico e relações sociais no mundo português. Vitória/Lisboa: EdUFES/IICT, 2006.

3

Segundo assinalado por Leslie Bethell, embora o número de embarcações utilizadas pela GrãBretanha na vigília da costa atlântica africana, ao longo da primeira metade do Oitocentos, seja consideravelmente alto, a atuação desta esquadra nunca fora, de fato, eficiente. Isso por três razões: $1^{\circ} 0$ estado obsoleto dos navios; $2^{\circ}$ A enorme extensão maritima a ser patrulhada; e $3^{\circ} 0$ acúmulo de deveres a serem cumpridos pela esquadra. Ver: BETHELL, Leslie. A abolição do tráfico de escravos no Brasil. A Grã-Bretanha, o Brasil e a questão do tráfico de escravos, 1807-1869. Rio de Janeiro/São Paulo: Expressão e Cultura/ EDUSP, 1976. p.125-127.

4

Roquinaldo Ferreira do Amaral apresenta uma rica análise em números, estatísticas, volumes e percentuais da reorientação do mercado escravista de Luanda (Angola) com destino a Cuba, ainda mais entre as décadas de 1840 e 1860, quando o tráfico para o Brasil começou a enfrentar novas e redobradas dificuldades que vão levar a sua extinção futura. AMARAL, Roquinaldo do. Dos sertões ao Atlântico: tráfico ilegal de escravos e comércio lícito em Angola. Dissertação de Mestrado. Universidade Federal do Rio de Janeiro, Centro de Filosofia e Ciências Humanas, 1996. Ver em especial o capítulo 8, "0 porto de Luanda e as relações com o Atlântico", p.200-215.

\section{Apresentação}

A década de 1840 representou um momento ímpar na campanha internacional pela supressão da comercialização de escravos africanos através do Atlântico. Isto porque, se até pouco tempo o abolicionismo podia ser descrito como um esforço diplomático e militar exclusivamente britânico, uma vez iniciado aquele novo decênio do Oitocentos, este se tornou uma investida intrinsecamente compartilhada por outras potências politicas e marítimas do Mundo Atlântico. ${ }^{1}$ A emergência deste novo contexto atlântico resultou num impacto profundo sobre as redes sociais, políticas e mercantis ligadas pelo comércio de almas. Sobretudo, para as duas grandes nações escravistas ainda remanescentes: a portuguesa e a brasileira. ${ }^{2}$

Entre 1807, quando a Coroa britânica proibiu seus súditos de tomarem parte no negócio negreiro, e o princípio da década de 1840, a Grã-Bretanha vinha, de fato, atuando praticamente sozinha no intento de abolir aquele comércio. Por meio da via diplomática, passados pouco mais de trinta anos desde que assumira o papel de polícia internacional contra o tráfico, ela conseguira: restringir o tráfico português aos domínios lusitanos na África e nas Américas (1810); proibir por inteiro a participação no mesmo da Holanda e da Suécia e confinar aos domínios da França o tráfico realizado pelos súditos da monarquia bourbônica (1814); obter de Portugal e da Espanha a interrupção de sua realização ao norte da Linha do Equador (1817); atrair para a sua causa boa parte das nações latino-americanas recém-independentes (1821-1822); garantir dos Estados Unidos o reconhecimento do tráfico enquanto pirataria (1824); e estabelecer um prazo limite para o comércio negreiro legal brasileiro (1826). Pela via militar, no mesmo período, a Grã-Bretanha ampliou significativamente o contingente material e pessoal de sua frota espalhada e estacionada ao longo da costa africana. Dos dois navios que a compunham em 1807, o Phesant e o Derwent, a esquadra atingiu o número de 14 embarcações em 1836, 17 em 1838 e 19 em 1839; nessa época, estima-se ainda que as estações marítimas britânicas na África reunissem um total de pouco mais de mil homens. ${ }^{3}$ Como se vê, as conquistas diplomáticas e a intensificação do patrulhamento marítimo obtidas e realizadas pela Grã-Bretanha no período são amplas e inegáveis. Todavia, não devemos supervalorizar o alcance dos seus efeitos práticos.

Ocorre que, desde os primeiros empecilhos e impedimentos impostos à navegação marítima de longa distância com o fito de traficar escravos saídos da África, os homens (comerciantes, capitães, mestres, tripulação em geral e intermediários) engajados nessa prática vinham apresentando uma incrivel capacidade de se (re)organizarem. 0 que, por conseguinte, implicava também numa renovação constante da empresa traficante como um todo. Exemplos disso não faltam. Enquanto a Espanha, em 1820, havia proibido interinamente o tráfico, tanto ao sul como ao norte do Equador, e, ainda, cedido à Royal Navy o direito de visita, busca e apreensão das embarcações sob a sua bandeira suspeitas de traficarem, os mercadores espanhóis interessados em continuar com o tráfico em direção a Cuba recorreram à bandeiras alternativas, como aconteceu inicialmente com a portuguesa e a brasileira. ${ }^{4}$ Da mesma forma, os mercadores brasileiros interessados em seguir com a importação de novos cativos, uma vez proibido o desembarque dos mesmos nos portos do Brasil a partir de novembro de 1831, redirecionaram o seu atracamento para portos intermitentes abertos em localidades mais afastadas donde se concentravam as forças de repres- 

propostas e experiências no final do tráfico de africanos para o Brasil (1800-1850). 2 ${ }^{\text {a }} \mathrm{ed}$. Campinas/São Paulo: Editora da Unicamp/CECULT, 2000. p.171-184.

\section{6}

Tratar dos navios negreiros exige um trabalho à parte, posto que a historicidade por trás destas embarcações é enorme e multifacetada. $\mathrm{Na}$ historiografia brasileira dois estudos pioneiros neste sentido são o de RODRIGUES, Jaime. Navios negreiros: imagens e descrições. In: De costa a costa: escravos, marinheiros e intermediários do tráfico negreiro de Angola ao Rio de Janeiro (1780-1860). São Paulo: Cia. das Letras, 2005. p.146-186; RAMBELLI, Gilson. Tráfico e navios negreiros: contribuição da arqueologia náutica e subaquática. In: Navigator: subsídios para a história maritima do Brasil. Rio de Janeiro: SDGM, v.2, n.4, p.59-72, 2006. Na historiografia estadunidense - que, assim como a brasileira, possui importantes obras a respeito do tráfico e da escravidão - merece destaque neste sentido o trabalho de CONRAD, Robert Edgar. Tumbeiros: o tráfico escravista para o Brasil. São Paulo: Brasiliense,1985; e, o estudo mais recente de REDIKER, Marcus. O navio negreiro: uma história humana. São Paulo: Cia. das Letras, 2011.

7

Segundo Bethell, a diplomacia das canhoneiras sempre fez parte da politica externa britânica Oitocentista. Todavia, até meados daquele século esta ocorria por conta do modo de agir imperialista e arrogante de uma série de diplomatas que sentindo-se isolados (muitos estavam há mais de três ou seis meses de distância do Foreign Office) utilizavam de medidas coercitivas, sobretudo de demonstrações de força no que se refere ao poder naval, para preservar os interesses políticos e econômicos das comunidades britânicas espalhadas pela América Latina. Todavia, teria sido apenas a partir da segunda metade do século XIX, após a ascensão de lord Palmerston ao cargo de Primeiro Ministro e, consequentemente, a confirmação do domínio dos palmerstonianos sobre o Foreign Office, que a diplomacia das canhoneiras passaria de fato à qualidade de princípio norteador dos diplomatas da Grã-Bretanha. A este respeito ver: BETHELL, Leslie. 0 imperialismo britânico e a Guerra do Paraguai. In: Estudos Avançados, São Paulo, v.9, n.24, p.269-285, 1995.

8

BETHEL, Leslie. A abolição do tráfico de escravos no Brasil... Op. Cit., p.27

9

Assim compartilham: CONRAD, Robert Edgar. Op. Cit., p.150; BETHELL, Leslie. A abolição do tráfico de escravos no Brasil... Op. Cit., p.36-37; e, WRIGHT, Antônia Fernanda Pacca de Almeida. Desafio americano à preponderância britânica no Brasil:1808-1850. 2ª ed. São Paulo: Brasiliense/ Instituto Nacional do Livro, 1978. p.228. são e patrulhamento. ${ }^{5}$ Ademais, em compasso com a esquadra britânica na África, que crescia consideravelmente, os traficantes das mais variadas nacionalidades procuraram responder ao tamanho com velocidade, optando por embarcações menores e de tecnologia náutica mais avançada como os clippers originários dos portos estadunidense em contraste com as belonaves arcaicas, velhas e pesadas utilizadas pela Grã-Bretanha na repressão ao tráfico atlântico de escravos. ${ }^{6}$

Estas e outras artimanhas postas em funcionamento pelos traficantes de escravos demonstram que, enquanto a Grã-Bretanha agiu isolada na supressão do tráfico atlântico de africanos este, embora tenha conhecido momentos e locais de reveses, não esteve verdadeiramente ameaçado de extinção. Na nossa concepção, por maior que fosse a influência política, econômica e militar da "poderosa rainha dos mares", esta jamais teria obtido sucesso em seu empreendimento abolicionista sem a ajuda das demais nações maritimas com as quais compartilhava o "condomínio do Atlântico". Destas, algumas optaram por conta própria em ingressar na frente abolicionista liderada pela Grã-Bretanha; outras, no entanto, tiveram de ser persuadidas pelo medo incutido através da diplomacia das canhoneiras. ${ }^{7}$ Entre as que decidiram agir de acordo com a primeira opção podemos listar a França e os Estados Unidos. Já entre as que preferiram a segunda alternativa, constavam Portugal e o Brasil.

Objetivos diversos levaram França e Estados Unidos a cooperarem com a Grã-Bretanha no combate ao fluxo transatlântico do comércio de escravos africanos. A França, embora estivesse formalmente alinhada, desde 1815, à política internacional abolicionista (lembrando ser esta a "fatura" cobrada por lord Castlereagh, então sob o comando do Foreign Office, a Luís XVIII pelos serviços britânicos prestados contra Napoleão), só veio a se envolver ativamente no concerto das nações em prol da abolição completa e definitiva do tráfico atlântico de escravos na transição da primeira para a segunda metade do século XIX, motivada basicamente por interesses imperialistas. ${ }^{8}$ Razões diversas do caso francês levaram os Estados Unidos, próximo ao fim do segundo quarto do Oitocentos, a assumirem uma postura mais concreta no combate do comércio transatlântico da mão de obra. Inversamente com o que vinha ocorrendo com as demais nações escravistas do "condomínio Atlântico", a legislação estadunidense contrária ao tráfico de escravos esteve longe de ser resultado de alguma forma de imposição ou cobrança britânica. Nesse tocante, os Estados Unidos foram totalmente autônomos e soberanos nas decisões por eles tomadas relativas a esta questão. Podem ser duas as explicações para isto: uma em razão da necessidade de salvaguardar a escravidão doméstica de flutuações externas que de alguma maneira viessem a intervir nos rumos daquela instituição, retirando das mãos dos próprios estadunidenses o direito de discutir e de legislar sobre a mesma; e a segunda em função da defesa dos próprios principios comerciais estadunidenses que de forma alguma aceitariam ver uma nação estrangeira determinar o que eles poderiam e o que não poderiam comercializar. ${ }^{9}$

De maneira nem um pouco análoga, no entanto, se deu a cooperação de Portugal e do Brasil. Embora politicamente mais instáveis, economicamente dependentes e militarmente mais frágeis, os diplomatas britânicos nunca se depararam, na realidade, com um ambiente amplamente favorável à causa abolicionista nas cortes de Lisboa e do Rio de Janeiro. Afora isto, por se tratar de duas sociedades extremamente imbricadas ao negócio negrei- 
ro, não foi difícil aos estadistas de ambas as monarquias reunirem o maior número de justificativas e, consequentemente, de subterfúgios para resistirem à imposição de medidas repressivas mais capazes e eficazes na extinção do tráfico humano intercontinental. Portugal apegou-se, ainda muito cedo, na fragilidade de sua posição enquanto metrópole de um império colonial convulsionado para retardar, o quanto Ihe foi possivel, a implantação de práticas mais austeras de retenção do comércio escravo africano. 0 Brasil, por sua vez, apegou-se na fragilidade de suas instituições político-estatais e, na "corrupção dos costumes" do povo brasileiro para adiar ao máximo uma condenação mais expressiva daquele que era o ramo comercial mais bem visto, aceito e compartilhado por sua sociedade. Em posse destes argumentos, os negociadores portugueses e brasileiros conseguiram impor aos negociadores britânicos um ritmo lento e arrastado às negociações, levando o governo britânico ao esgotamento de todas as vias diplomáticas antes de optar unilateralmente pela via militar para sobrepor os seus interesses abolicionistas aos interesses escravagistas de portugueses e brasileiros.

Entendendo, portanto, que Portugal e Brasil passaram por situações e complicações minimamente semelhantes e, muitas vezes, convergentes em torno da questão do contrabando de africanos, este texto tem por objetivo explorar o papel predominante que a referida questão do comércio negreiro exerceu sobre o estabelecimento das primeiras relações entre ambos os paises. A diplomacia do tráfico de Portugal e do Brasil é, pois, o elemento aglutinador deste trabalho. Com efeito, ao longo das próximas páginas, 0 enquadramento anglo-brasileiro em face da abolição do "infame comércio" de escravos dará espaço às vicissitudes do enquadramento luso-brasileiro sobre a mesma questão.

0 foco de análise do presente trabalho originou-se mediante a confluência de alguns textos-chaves da historiografia brasileira e portuguesa quanto à questão do tráfico de escravos, bem como a partir do estudo do historiador inglês Leslie Bethell sobre o peso desta questão nas relações da Grã-Bretanha com o Brasil e Portugal. Quanto à massa documental deste artigo, esta é composta, basicamente, por informações extraídas dos Relatórios apresentados pelos Ministros dos Negócios Estrangeiros do Império, entre as décadas de 1830 e de 1840.

Num primeiro momento buscar-se-á responder a duas questões fundamentais: $1^{\circ}$. 0 que denominamos aqui como diplomacia do tráfico? $2^{\circ}$. Qual o percurso histórico desta diplomacia em Portugal e no Brasil? Respondidas estas indagações, o segundo momento deste texto visa expor de que forma esta postura diplomática teria repercutido no âmago das relações formais luso-brasileiras de meados do Oitocentos, quando o ambiente político bilateral entre Portugal e Brasil esteve a ponto de um impasse devido às expectativas divergentes esperadas de um lado a outro do Atlântico para com esta diplomacia. 0 terceiro momento deste trabalho versará sobre 0 abandono da diplomacia do tráfico por ambos os países a partir da triangulação das relações de Portugal e do Brasil com a Grã-Bretanha. 0 quarto e último momento deste estudo buscará amarrar a discussão ao esclarecer a fonte de origem de nosso interesse e de nossas interrogações sobre o tema posto aqui em evidência.

\section{A diplomacia do tráfico de Portugal e do Brasil}

Em linhas gerais, o conceito de diplomacia do tráfico deve ser apreendido como o conjunto de reações políticas de âmbito internacional, grosso modo 
Compartilhamos aqui do ponto de vista de Waddell, que entende o sistema atlântico ou, caso se prefira, americano - como um subsistema, isto no curso da transição do Setecentos para o Oitocentos, de um sistema político maior: o europeu. Ver: WADDELL, D. A. G. A politica internacional e a independência da América Latina. In: BETHELL, Leslie (Org.). História da América Latina. Vol. III: Da independência até 1870. São Paulo: EdUSP/Imprensa Oficial do Estado/Fundação Alexandre de Gusmão, 2004. p.231-265.

11

Ao adotarmos o termo política da escravidão utilizamos a significação semântica fornecida por Tâmis Parron, que a entende como sendo uma rede de alianças políticas e sociais costuradas em favor da estabilidade institucional da ordem escravista. Este conceito, tal qual nos lembra o autor, é costumeiramente empregado por historiadores dos Estados Unidos para designar o conjunto de valores e práticas que direcionavam os eleitores sulistas na escolha de seus candidatos ao Congresso Nacional, com vista a salvaguardar não só a continuidade, mas também a própria expansão - para os novos territórios do sudoeste - do sistema escravista. Ver: PARRON, Tâmis. A política da escravidão no Império do Brasil, 1826-1865. Rio de Janeiro: Civilização Brasileira, 2011. p.17-19.

12

Para o leitor interessado na realidade do sistema escravista desenvolvido em Cuba e no sul dos Estados Unidos, um texto referencial para a formulação de ideias neste sentido é o de MARQUESE, Rafael de Bivar. Feitores do corpo, missionários da mente. Senhores, letrados e 0 controle dos escravos nas Américas, 1660-1860. São Paulo: Cia das Letras, 2004.

13

ALMEIDA, Paulo Roberto de. Formação da diplomacia econômica no Brasil: as relações econômicas internacionais no Império. Vol. I. São Paulo/Brasília: SENAC/FUNAC, 2001. p.315.

14

Ibidem, p.317.

15

Clara referência, obviamente, ao trabalho conjunto de FRAGOSO, João; FLORENTINO, Manolo. $O$ arcaísmo como projeto: mercado atlântico, sociedade agrária e elite mercantil em uma economia colonial tardia - Rio de Janeiro, c 1790 - c. $1840.4^{\text {a }}$ ed. Rio de Janeiro: Civilização Brasileira, 2001

16

Para uma leitura dos pormenores da ideia de edificação do Império luso-brasileiro ver LYRA, Maria de Lourdes Viana. A utopia do poderoso império. Portugal e Brasil: bastidores da politica, 1798-1822. São Paulo: Sette Letras, 1994. Um segundo trabalho referencial para a compreensão deste grande empreendimento que foi a criação de um Império extracontinental, porém com uma visão acadêmica portuguesa do tema, é a coletânea de NIZZA DA SILVA, Maria Beatriz (Org.). Nova história da expansão portuguesa. 0 Império luso-brasileiro (1750-1822). Lisboa: Estampa, 1986. unilateral, posto em prática por Estados intrínseca e diretamente ligados à comercialização da mão de obra escrava africana, a saber: Brasil, Portugal, Espanha (à época, ainda metrópole de uma das principais zonas importadoras de escravos do Atlântico: Cuba) e mesmo os Estados Unidos - frente à intensificação da questão abolicionista na agenda internacional dos países integrantes do sistema atlântico ${ }^{10}$ ao longo da primeira metade do século XIX. Nesse sentido, não é estranho afirmar que, dentro do contexto e dos valores assumidos pelo sistema escravista nas realidades específicas dos referidos paises, a diplomacia do tráfico esteve, de um modo ou de outro, ligada e referendada pela política da escravidão $0^{11}$ em voga nos mesmos. Para os fins argumentativos deste trabalho convém, no entanto, ater nossa explanação ao caráter significante desta diplomacia em Portugal e no Brasil, bem como ao percurso histórico que a mesma veio a sofrer em ambos os paises. ${ }^{12}$

Como observado pelo diplomata e cientista político Paulo Roberto de Almeida, os primeiros passos da diplomacia do tráfico de Portugal e do Brasil foram galgados quando das negociações que se seguiram a transferência do aparato administrativo da monarquia bragantina para o Rio de Janeiro em 1807-8, cujo resultado foi o Tratado de Paz e Amizade de 1810 entre Portugal e a Grã-Bretanha ${ }^{13}$, pelo qual, em seu art. 10, "o Príncipe Regente concordava na abolição gradual do tráfico de escravos e passava a permiti-lo [unicamente] nas possessões portuguesas da África para o Brasil".14 A historiografia especializada é unânime em identificar este momento como a ocasião em que são colocados os primeiros óbices ao comércio negreiro realizado por portugueses e brasileiros. Haja vista que, nas negociações bilaterais estabelecidas entre os agentes portugueses e britânicos no decênio seguinte à assinatura e ratificação deste tratado, a concordância ali registrada de D. João configurou num dos principais torniquetes de pressão utilizados pelos diplomatas de Sua Majestade Britânica para advogar contra o tráfico de africanos realizado pelos súditos de Sua Alteza Fidelíssima. De modo semelhante, no entanto, a contratação do Tratado de 1810 pode muito bem ser identificada como a ocasião em que foi gestada a postura diplomática luso-brasileira em prol da defesa do tráfico desenvolvido pelos vassalos do Estado bragantino. Afinal, ali estão coladas promessas - aliás, muito vagas -, cujo fito era não outro que transferir a questão do tráfico atlântico de escravos para as mesas de negociações futuras. Tática esta repetidamente empregada pela diplomacia a princípio luso-brasileira e, posteriormente a 1822, pelas diplomacias reinol e imperial de Portugal e Brasil respectivamente.

Essa tese ganha substância quando atrelada à ideia do projeto continuísta - ou, em outras palavras, do "arcaísmo como projeto"15 - que se encontra por trás da invenção e edificação, à época da negociação do Tratado de 1810, do Império luso-brasileiro. E, que, por sinal, vai estar também presente algum tempo depois nos embates políticos e ideológicos em torno da concepção do próprio Estado imperial brasileiro. Em ambos os tempos, buscou-se estabelecer um novo contrato imperial e social entre o(s) monarca(s) e as elites dirigentes e constituintes hora do Império extracontinental luso-brasileiro, hora do contínuo e indivisivel Império brasileiro, por meio dos quais a lealdade e fidelidade para com a Casa de Bragança dependiam consequentemente da capacidade das instituições monárquicas em identificar, congregar e defender os interesses elitistas não só no plano interno, mas também no plano externo da ordem imperial. ${ }^{16}$ Nesse sentido, Demétrio Magnoli é enfático quando diz que: 
MAGNOLI, Demétrio. 0 corpo da pátria: imaginação geográfica e política externa no Brasil (1808-1912). São Paulo: Editora UNESP/ Moderna, 1997. p.86.

18

0 termo partidário, aqui utilizado, difere da conotação contemporânea que o identifica como sendo uma pessoa ligada a um partido político, a um sistema ou a um regime de governo. Ele restringe, tão somente, à rivalidade dos círculos políticos do Império luso-brasileiro, verificada nos primeiros anos da década de 1820, entre os estadistas identificados com os interesses políticos e econômicos do Brasil e aqueles identificados às aspirações políticas e econômicas de Portugal. Para uma visão mais plena deste contexto ver RIBEIRO, Gladys Sabina. A liberdade em construção. Identidade nacional e conflitos antilusitanos no Primeiro Reinado. Rio de Janeiro: FAPERJ/Relume Dumará, 2002.

19

Compartilhamos aqui da visão dos professores Cervo e Bueno. Segundo eles, o Estado brasileiro [que] se apresenta à comunidade internacional, em 1822, reivindicando o papel de novo membro e ator (...) pouco tinha [na realidade] de brasileiro na medida em que representava o transplante direto do Estado português. Ver: CERVO, Amado; BUENO, Clodoaldo. História da política exterior do Brasil. São Paulo: Ática, 1992. p.20-25.

20

Preâmbulo do Tratado de Paz e Aliança entre Brasil e Portugal, de 1825. Apud. CERVO, Amado; MAGALHÃES, José Calvet de. Depois das caravelas. As relações entre Portugal e Brasil: 1808-2000. Brasilia: Editora da UnB, 2000. p.377-381.

21

ACCIOLY, Hildebrando. O reconhecimento da Independência do Brasil. Rio de Janeiro: Imprensa Nacional, 1927. p.120.
[...] 0 apego da Coroa à atividade negreira está acima de qualquer suspeita [pois]: em 1810, D. João VI curvou-se ao compromisso genérico de abolição gradual do tráfico apenas para evitar retaliações mais duras; em 1815, sacrificou o comércio negreiro ao norte do Equador em nome de uma relativa tolerância britânica no Hemisfério Sul; [enquanto que] a partir de 1822, o governo imperial travou uma verdadeira guerra de posição, trincheira por trincheira, a fim de conferir sobrevida inesperadamente longa ao lucrativo negócio. ${ }^{17}$

A razão disto é que, a diplomacia do tráfico gestada no seio da monarquia bragantina no contexto político da afirmação da união luso-brasileira, ou seja, na década de 1810, tinha por duplo objetivo retardar ao máximo a condenação efetiva do comércio de escravos com vista a fortalecer e estreitar o vasto sistema comercial existente entre os territórios portugueses na América e na África forjado, justamente, a partir das rotas maritimas a serviço da exportação e da importação de mão de obra cativa de uma costa a outra do Atlântico. Esperava-se com isto que, esta mesma diplomacia auxiliasse no plano político interno de reorganização do Império Ultramarino - que então se queria identificar como lusitano e brasileiro - na medida em que ela impedisse no plano político internacional a intervenção britânica no destino do principal produto de comercialização ou seja, o escravo - entre as praças mercantis atlânticas constituintes do mesmo Império. Todavia, o caráter aglutinador desse grandioso projeto encabeçado e vislumbrado pela Casa de Bragança, não foi suficiente para impedir a proliferação de pontos de vistas divergentes entre os estadistas representantes das elites de Portugal e do Brasil. Não obstante, nos quatro últimos anos daquela década assistiu-se a uma crescente divisão entre portugueses e brasileiros que resultou, ao fim, na melindrosa cisão entre os partidários ${ }^{18}$ de uma e de outra causa traduzida na efetivação, em princípios dos anos de 1820, da Independência do Brasil.

A separação política entre Portugal e o Brasil não levou, entretanto, ao fim da monarquia bragantina nem lá e nem cá. Pelo contrário, tanto 0 Brasil como o próprio Portugal, seguiram sendo básica e indistintamente um Estado bragantino, sobretudo, no que diz respeito à forma de relacionar-se internacionalmente com outros Estados ao buscar prolongar conversações, contornar agravantes e negociar simultaneamente com mais de um Estado em diferentes frentes e situações. ${ }^{19}$ De modo análogo, a dissensão luso-brasileira também não assinalou o abandono da diplomacia do tráfico nem de um lado nem de outro do Atlântico. A despeito disso, ela repercutiu no sentido de definir clara e objetivamente as pretensões específicas que portugueses e brasileiros esperavam obter em relação à questão do "infame comércio" de escravos.

Com base em nossa historiografia, é possivel que os anseios brasileiros acerca do tráfico de africanos nos sejam mais claros. Celebrado o Tratado de Paz e Aliança de 1825, "entre o Senhor D. Pedro I, Imperador do Brasil, e D. João VI, Rei de Portugal" 20 , pelo qual o Império brasileiro obteve "o reconhecimento da [sua] personalidade internacional "21, a diplomacia do Primeiro Reinado buscou com afinco renovar os termos adotados com a Grã-Bretanha para reger as rodadas de negociação sobre a concessão do reconhecimento britânico à Independência brasileira. Desde 1824, quando a primeira rodada bilateral de negociação teve lugar em Londres, a estratégia brasileira era a de cercar o comércio escravista de subterfúgios que o salvaguardassem na mesa de negociação. Desta feita, os plenipotenciários imperiais credenciados àquele tempo junto à Corte de Saint James, 
22

Para uma leitura mais específica e consubstancial das negociações anglo-brasileiras durante a década de 1820, além da obra de Leslie Bethell, A abolição do tráfico de escravos para o Brasil, aqui já referida, indica-se também outros importantes trabalhos como: CALÓGERAS João Pandiá. A política exterior do Império. Vol. II: o Primeiro Reinado. Brasília: Senado Federal, 1998; RODRIGUES, José Honório. Independência: revolução e contra-revolução. Vol. 5: a política internacional. Rio de Janeiro: Francisco Alves, 1975; PANTALEÃO, Olga. A presença inglesa no Brasil/0 reconhecimento do Império. In: HOLANDA, Sérgio Buarque de (Org.). História geral da civilização brasileira. Tomo II: 0 Brasil monárquico. Vol.I - 0 processo de emancipação. $5^{a}$ ed. São Paulo: Difel, 1982. p.64-99 e p.331378.

23

BETHELL, Leslie. A abolição do tráfico de escravos para o Brasil... Op. Cit., p.39-40.

24

Ibidem, p.41.

25

Cabe aqui uma explicação pontual. Por muito tempo a historiografia tomou o Tratado anglo-brasileiro de 1826 como uma derrota à diplomacia do tráfico do Primeiro Reinado. Tal visão, em grande parte, se justifica em face da cláusula nele firmada de abolição do tráfico de escravos para o Brasil passados três anos de sua ratificação pelos respectivos governos contratantes. Todavia, para além desta determinação, a historiografia que se debruçou sobre o Tratado de 1826 foi também muito influenciada pela impressão negativa que o sistema de tratados tinha despertado no Poder Legislativo nacional que, àquela altura, já iniciava a sua campanha pelo fortalecimento das instituições parlamentares. Desta forma, a historiografia mais tradicional deixou-se, em certa medida, contaminar-se pela visão "do insucesso", criada pelos parlamentares a partir de 1826, o que impediu que se apreendessem os sucessivos esforços travados pelos diplomatas brasileiros desde 1822 para salvaguardar o tráfico de escravos.
Felisberto Caldeira Brant - futuro marquês de Barbacena - e Gameiro Pessoa, haviam sido instruídos por Luís José de Carvalho e Mello, então Ministro dos Negócios Estrangeiros, a esgotarem todas as argumentações relativas às vantagens comerciais que o reconhecimento poderia advir para a Grã-Bretanha antes que eles próprios fossem inquiridos a tratar da delicada questão do tráfico atlântico de escravos. ${ }^{22}$ Solucionado, porém, 0 impasse com Portugal, os agentes brasileiros não deixaram que as novas implicações internacionais que o tratado luso-brasileiro de 1825 então introduzia no contexto particular das relações do Império com o continente africano passassem despercebidas.

Reconhecido, agora, formalmente como um Estado independente e soberano por sua antiga metrópole, era juridicamente reconhecido também ao Brasil protestar contra a validade e a continuidade de obrigações internacionais que transcendiam a sua emancipação. Nesse sentido, abria-se um caminho legal de contestação por parte do Império no foro internacional de princípios do século XIX, no qual a Grã-Bretanha desenvolverá múltiplos acordos bilaterais com vista a reprimir e sufocar o tráfico negreiro intercontinental, na medida em que os convênios de 1810, 1815 e de 1817 diziam respeito ao "comércio de almas" realizado por brasileiros enquanto súditos do rei de Portugal. Liberados da relação de vassalagem com o monarca lusitano, não tinham, portanto, aquelas cláusulas restritivas e proibitivas efeito prático ou legal algum sobre os súditos do Imperador do Brasil. Em outras palavras, o Império em si não havia até então firmado compromisso algum de abolição daquele comércio. Na realidade, esta lógica brasileira promoveu uma inversão do próprio entendimento britânico sobre a legalidade do tráfico de escravos desenvolvido pelos portugueses em meio ao calor dos acontecimentos de Setembro de 1822. Posto que, George Canning, à época Ministro do Exterior da Grã-Bretanha:

[...] pôde argumentar, com justiça, que todo o tráfico português de escravos através do Atlântico se tornara de facto ilegal a partir do momento em que o Brasil e Portugal se haviam separado (...). [Com base no] artigo quarto do tratado de 1815, D. João tinha se comprometido especificamente a não permitir que a bandeira portuguesa fosse empregada no tráfico negreiro, exceto para suprir de mão de obra "as possessões transatlânticas pertencentes à coroa de Portugal"; [da mesma forma que] o artigo primeiro da Convenção Adicional de 1817 tinha definido como ilícito o tráfico exercido por navios portugueses para portos situados fora dos domínios da coroa portuguesa $[. . .]^{23}$

Com razão, Bethell argumenta que "o que parecia representar um passo à frente" para se alcançar mais rapidamente o intento britânico da abolição definitiva do tráfico no Atlântico Sul, "a curto prazo, acabou por representar também dois passos atrás" 24 . Prova disto é o favorecimento que se seguiu, após a ruptura luso-brasileira, à diplomacia do tráfico do Brasil que foi ali enriquecida por novos elementos - além da retórica da necessidade de novos "braços para a lavoura" nacional - para lutar pela postergação do comércio humano entre a África e o Brasil. ${ }^{25}$

Como mencionado há alguns parágrafos atrás, o fim da união luso-brasileira não simbolizou, em Portugal, a supressão de sua diplomacia do tráfico. Ainda que entre 1810 e 1822, esta diplomacia estivesse mais identificada com os anseios da porção americana do Império luso-brasileiro, o período que se segue à extinção da monarquia transcontinental bragantina revela que os portugueses também tinham grande interesse em 
26

A importância da embarcação dos escravos, bem como das demais atividades do negócio negreiro para os cofres públicos de Portugal ao longo do século XIX pode ser verificada no trabalho de LAINS, Pedro. Causas do colonialismo português em África, 1822-1975. In: Análise Social, Lisboa, Instituto de Ciências Sociais da Universidade de Lisboa, v.XXXIII, n.146-147, p.463-496, 1998. (Ver em especial as páginas 467 a 476).

27

ALEXANDRE, Valentim. 0 império português (1825-1890): Ideologia e economia. In: Análise Social, Lisboa, Instituto de Ciências Sociais da Universidade de Lisboa, v.XXXVIII, n.169, p.959979, 2004. (citação literal da página 960).

28

Seguimos aqui a noção de comunidade de traficantes fornecida por Florentino, de forma que a entendemos como uma rede de relações que extrapolava o âmbito econômico, estendendo-se ao campo pessoal e afetivo. Ver: FLORENTINO, Manolo. Em costas negras: uma história do tráfico atlântico de escravos entre a África e o Rio de Janeiro (Séculos XVIII e XIX). Rio de Janeiro: Arquivo Nacional, 1995. p.219-222.

29

Eusébio de Queirós Coutinho era pai de Eusébio de Queirós Coutinho Matoso Câmara, justamente um dos líderes da Trindade Saquarema e Ministro da Justiça responsável, em 1850, pela repressão ao tráfico atlântico de escravos. A relação da familia dos Queirós com a política brasileira se dá, por conseguinte, a partir da passagem do Eusébio pai pelo Rio de Janeiro, em 1822, quando este seguia para Lisboa a fim de tomar seu assento nas Cortes Constitucionais como um dos representantes eleitos por Angola. Ver: RODRIGUES, José Honório. Brasil e África: outros horizontes. Vol.I - Relações e contribuições mútuas. Rio de Janeiro: Civilização Brasileira, 1964. p.133-137.

30

COSTA E SILVA, Alberto da. Um rio chamado Atlântico:a África no Brasil e o Brasil na África. Rio de Janeiro: Nova Fronteira/Ed. UFRJ, 2003. p.32.

31

Artigo 3 do Tratado de Paz e Aliança entre Brasil e Portugal, de 1825. Apud. CERVO, Amado; MAGALHÃES, José Calvet de. Depois das caravelas... Op. Cit., p.379.

32

ALEXANDRE, Valentim. Portugal e a abolição do tráfico de escravos (1834-1851). Análise Social, Lisboa, Instituto de Ciências Sociais da Universidade de Lisboa, v.XXVI, n.111, p.293-333, 1991 (citação literal da página 301). refrear a intervenção britânica sobre o negócio negreiro no Atlântico Sul. Tal qual no Brasil, onde a possibilidade de extinção imediata e definitiva do tráfico de escravos causou grande alarme sobre o futuro da arrecadação fiscal do Estado, em Portugal, devido à parca receita dos cofres públicos em sua maior parte proveniente dos impostos sobre os cativos embarcados e sobre as demais operações mercantis concretizadas no cerne da mesma prática escravista, a preocupação com a deflagração de uma longa e grave crise econômica também se fez presente. ${ }^{26}$

A este quadro deve ainda ser acrescentada uma segunda preocupação, de ordem fundamentalmente política. Ocorre que, após a Independência do Brasil, Portugal conservava ainda no seu rol de territórios, domínios e entrepostos a posse de importantes zonas de exportação de mão de obra africana. Vide, por exemplo, os portos de Luanda, Benguela e Cabinda, em Angola. Contudo, como bem lembrado pelo historiador português Valentim Alexandre, até meados do século XIX, "a soberania de Lisboa sobre estas e outras regiões pouco mais era do que nominal, estando o(s) governo(s) das colônias entregue(s) de fato aos estratos dominantes locais"27 historicamente vinculados às atividades do comércio negreiro. Posto isto, é de se imaginar a complexidade da questão do tráfico para a política ultramarina do Estado português. Paralelamente, enquanto no Brasil dos anos de 1820 a defesa do negócio escravista monopolizado por uma comunidade de traficante ${ }^{28}$ marcadamente carioca, apresenta-se como uma das atribuições chave do novo Estado imperial, sendo esta inclusive uma das principais fontes de sua legitimidade, no mesmo período, em Portugal, a conservação do tráfico atlântico de escravos oferecia-se como solução à proliferação de perturbações regionais que pudessem levar a novas desarticulações do império ultramarino português remanescente.

Não era injustificável o temor português. Ainda durante a última fase do Império luso-brasileiro, quando da convocação das Cortes de Lisboa (1821-1822), Euzébio de Queirós Coutinho, um dos três representantes eleitos para representar Angola em Portugal, era um dos mais fervorosos simpatizantes à ideia de separação deste último de sua terra natal e de sua adesão ao Império do Brasil. ${ }^{29}$ Outro exemplo singular que mostra o quão grande era o número de partidários da causa emancipacionista brasileira na colônia angolana sucedeu-se em Benguela, quase que ao mesmo tempo em que o governo do Rio de Janeiro declarava a sua autonomia em relação ao de Lisboa, tendo a cidade sido tomada por uma sucessão de revoltas em favor da anexação com o Brasil. ${ }^{30}$ Estes episódios resultaram diretamente no Tratado luso-brasileiro de 1825 - mediado pela diplomacia britânica -, pelo qual, Sua Majestade Imperial, ou seja, D. Pedro I prometia "não aceitar proposições de quaisquer colônias portuguesas para se reunirem ao Império do Brasil". ${ }^{31}$ Ainda assim, a posição metropolitana de Portugal ante as pressões abolicionistas do tráfico de africanos emanadas da Grã-Bretanha era relativamente frágil:

\footnotetext{
[...] Aceitar o compromisso de abolir o tráfico (...) envolvia (...) um duplo perigo: 0 de mostrar a incapacidade do Estado português para levar a cabo a parte que the caberia em tal tarefa, abrindo a porta a novas pressões inglesas; e o de suscitar uma sublevação nas possessões africanas, provocando a dissolução do que restava [de seu] império [...]..$^{32}$
}

Dada tal realidade e guardadas as devidas proporções, é possivel perceber certa similitude entre o dilema dos estadistas vintistas do Brasil 
33

As relações bilaterais de Brasil e Portugal eram, na realidade, mais complexas, envolvendo interesses divergentes de ambos os lados. Do lado brasileiro, demonstrava-se ainda o interesse pelos seguintes temas: fabricação e contrabando de moeda falsa e a liquidação dos prejuizos reclamados por Portugal quando da Guerra de Independência. Já do lado português constavam como principal ponto de pauta a coibição da emigração clandestina de portugueses para - Brasil e a proteção dos bens e dos súditos portugueses que se encontravam e que residiam no Brasil. Apesar desta agenda variada, naqueles anos de 1830 , foi a coibição do tráfico atlântico feito debaixo da bandeira portuguesa que servira como ponto catalisador das relações entre ambos os paises. CERVO, Amado Luiz; MAGALHÃES, José Calvet de. Depois das caravelas... Op. Cit., p.129-168.

34

Relatório da Repartição dos Negócios

Estrangeiros, 1834, p.4. e de Portugal acerca da questão da abolição do tráfico de escravos de seus respectivos patrícios. Em ambos os casos a supressão do negócio negreiro trazia consigo: um risco real à ordem econômica e política dos dois Estados escravistas; e uma implicação de ineficiência ou, mesmo, de falência das respectivas instituições de governo, principalmente no que toca ao gerenciamento de suas políticas externas. Sendo, deste modo, altamente custoso a ambos os paises enfrentarem, naquele momento, o ônus da abolição. $A$ diplomacia do tráfico que neles teve lugar no decorrer da década de 20 do Oitocentos, embora objetivasse atender a anseios e projetos peculiares buscou, de forma parelha, esquivar-se ao máximo da pressão diplomática exercida pela Grã-Bretanha. Em algumas ocasiões optou-se, inclusive, por aguardar que uma das partes pressionadas tomasse a iniciativa decisória de acabar com o tráfico. 0 que, por conseguinte, desembocou na década de 1830 num ambiente conflituoso das relações luso-brasileiras.

\section{0 "empurra-empurra" entre Portugal e o Brasil}

Depois da Grã-Bretanha, foi com Portugal que o Brasil mais se ateve na discussão da supressão do tráfico negreiro através do Atlântico Sul. A razão disto se deve, quase que essencialmente, à participação da bandeira portuguesa no contrabando para o Brasil..$^{33}$ Evento corriqueiramente chamado à atenção nos Relatórios Ministeriais da Repartição dos Negócios Estrangeiros do Império, a exemplo do que se lê no Relatório de 1834, assinado por Aureliano de Souza e Oliveira Coutinho:

[À] comissão mista brasileira e inglesa (...) para o julgamento do contrabando de africanos, foram presentes dois casos de duas embarcações portuguesas: a barca - Maria da Glória - e o bergantim - Paquete do Sul -, detidas a 1a. Pelo brigue de guerra inglês - Snake -, pois the acharam 426 africanos a bordo, e a 2a. Pela corveta inglesa - Satellite -, por se Ihe encontrarem ferros, e utensilios próprios para o tráfico de escravos. Aquela barca não foi sentenciada pela Comissão por se ter provado ser de propriedade portuguesa (...) o bergantim porém o foi somente naquela parte do valor pertencente a um súdito brasileiro. A tomada destas embarcações deveria talvez desanimar um tráfico tão desumano, e impolítico, o qual todavia continua, e continuará a fazer-se nas costas do Brasil, a despeito da Lei de 7 de novembro de 1831, e das reiteradas ordens, e recomendações do governo a tal respeito às autoridades subalternas; porquanto, primeiramente tem sido protegido pela bandeira portuguesa, como o provam as duas embarcações acima mencionadas, e outros fatos. Navios cobertos com a referida bandeira partem continuamente de nossos portos com o especioso pretexto de carregarem na costa da África marfim, cera, azeite, e outros artigos de comércio, levando porém a intenção fixa de só trazerem infelizes africanos, que Ihes afiançam um melhor lucro [...] Sobre a proteção da bandeira portuguesa a tais navios tem já o governo imperial oficiado de uma maneira enérgica à Legação de Sua Majestade Fidelíssima nesta Corte; bem como tem reclamado a intervenção do governo inglês, para que se consiga a proibição deste desumano tráfico nas colônias portuguesas. ${ }^{34}$

E, no de seu sucessor, o Ministro Manuel Alves Branco:

A comissão mista brasileira e inglesa (...) tem tomado conhecimento de várias embarcações, que tem sido apreendidas por vasos de guerra brasileiros, e ingleses a saber - Duquesa de Bragança; [os] patachos Dois de Março e Santo Antônio; [e o] bergantim Rio da Prata. Foi o primeiro apresado pela corveta de guerra Satellite com 227 africanos; o segundo pelo brigue Cacique, e [pela] escuna Fluminense, por desconfiança de ter trazido africanos; o terceiro pela escuna de guerra brasileira Lebre, com 144 africanos; o quarto pela corveta de guerra inglesa Raleigh com 523 africanos. Sendo todas as embarcações condenadas, apenas deixou a Comissão de 
Relatório da Repartição dos Negócios Estrangeiros, 1835, p.4-5.

36

A lei de 1831 foi por muito tempo considerada uma lei ineficiente por parte da comunidade acadêmica que, aliás, fazia questão de reforçar o estigma negativo por trás da denominação "lei para inglês ver". Contudo, já faz algum tempo que uma vertente da historiografia nacional tem chamado a atenção para outro caráter da lei de 1831 que não o jurídico: o seu caráter político. Nesse sentido, são instigantes os trabalhos de Beiguelman e de Mamigonian. Ambas as autoras reconhecem o trabalho legislativo acerca da regulamentação da extinção e da proibição do comércio negreiro para o Brasil impetrado durante a Regência (1831-1840) como uma tentativa do próprio legislativo de (re)afirmar a sua soberania sobre o Estado brasileiro e, por conseguinte, sobre as comissões mistas anglo-brasileiras. Estas foram criadas, com base nas estipulações acertadas no Tratado de 1826, para julgar as presas realizadas a partir de 13 de março de 1830, quando o tráfico entre a África e o Brasil deveria, pelo referido convênio internacional, cessar de vez. Este artigo compartilha dessa visão história. Ver: BIGUELMAN, Paula. Formação política do Brasil. Vol. I: Teoria e ação no pensamento abolicionista. São Paulo: Pioneira, 1976. MAMIGONIAM, Beatriz Gallotti. 0 direito de ser africano livre: os escravos e as interpretações da Lei de 1831. In: LARA, Silvia Hunold; MENDONÇA, Joseli Maria Nunes (Orgs.). Direito e justiça no Brasil: ensaios de história social. Campinas: Editora da Unicamp, 2006. p.129-169.

37

AMARAL, Roquinaldo do. 0p. Cit., p.136. ALEXANDRE, Valentim. Portugal e a abolição do tráfico de escravos... Op. Cit., p.297.

38

Da mesma forma com que grande parte das autoridades brasileiras eram suscetiveis ao tráfico e aos traficantes, era também conhecida a conivência com que autoridades portuguesas, no Brasil e/ou nos portos da África, tinham para com a dita prática e os ditos indivíduos. AMARAL, Roquinaldo do. Op. Cit., p.117-148 e p.216-233. tomar conhecimento do patacho Dois de Março, por se verificar ser propriedade portuguesa e, por conseguinte, fora da letra do tratado, de que ela recebeu autorização. 0 governo, guiado tanto pelos princípios de humanidade, como fiel aos tratados, e à Lei de 7 de novembro de 1831, tem desveladamente procurado velar o contrabando de africanos, que escandalosamente continua a fazer-se em todo o Brasil; mas os esforços do governo, é doloroso dizê-lo, tem sido quase baldados, atenta a facilidade que encontram os armadores daquelas embarcações nas colônias portuguesas, usando da sua bandeira por meio de vendas fraudulentas [...] ${ }^{35}$

Ocorre que o uso da bandeira portuguesa no contrabando de africanos foi um dos primeiros indícios, após os primeiros anos da proibição do comércio atlântico de escravos para o Brasil, depois da lei de 7 de novembro de $1831^{36}$, de que este estava se renovando. 0 procedimento era simples. Primeiro, era simulada a venda de uma embarcação qualquer de um brasileiro para um português. Feito isto, o seu novo proprietário dava entrada, junto ao Consulado português no Rio de Janeiro, no requerimento dos documentos que the garantiam o direito de navegar para qualquer que fosse o porto africano sobre a autoridade de Portugal. 0 pretexto declarado para a viagem, como enunciado pelo Ministro Oliveira Coutinho, era o de carregar na costa da África marfim, cera, azeite e outros artigos de comércio. Mas o motivo real era mesmo o de traficar escravos livre das proibições que recaíam sobre as embarcações de proprietários brasileiros. ${ }^{37}$

A ousadia dos traficantes era tamanha, e a conivência do cônsul português no Rio de Janeiro, Joaquim Barrozo Pereira, era tão escancarada ${ }^{38}$ que, em 1836, o Ministro dos Estrangeiros do Império, Ignácio Borges, informava que sete embarcações sob a bandeira portuguesa haviam passado pela comissão mista anglo-brasileira instalada no Rio de Janeiro, conforme apresentado na tabela abaixo:

\section{Navios Negreiros Apresados sob a Bandeira Portuguesa entre Maio de 1835 a Maio de 1836}

\begin{tabular}{llc}
\hline Tipo de Embarcação & Identificação & Escravos a Bordo \\
\hline Bergantim & Amizade Feliz & 350 \\
\hline Escuna & Angélica & 319 \\
Patacho & Continente & 60 \\
\hline Bergantim & Aventura & - \\
Sumaca & Novo Destino & 2 \\
\hline Brigue & Orion & 243 \\
\hline Sumaca & Vencedora & - \\
\hline
\end{tabular}

FONTE: Relatório da Repartição dos Negócios Estrangeiros, 1836, p.4

0 crescimento desta prática ano após ano era, portanto, evidente. Contudo, mais preocupante do que a situação de 1836, iria se mostrar a de 1838. Dois anos depois da vertiginosa elevação do número de embarcações portuguesas apresadas pelas comissões mistas anglo-brasileira, Antônio Peregrino Maciel Monteiro, denunciava: 
39

Relatório da Repartição dos Negócios Estrangeiros, 1838, p.14-15.

40

Relatório da Repartição dos Negócios Estrangeiros, 1835, p.5.

41

COSTA e SILVA, Alberto. 0p. Cit., p.31. Três foram as tentativas do governo brasileiro, ao longo da primeira metade do século XIX em estabelecer um consulado em Luanda. A primeira se deu entre os fins de outubro de 1826 e os idos de novembro de 1827, quando Rui Germak Possolo chegou a assentar serviço em Luanda até ser expulso pelo governador de Angola, Nicolau de Abreu Castelo Branco. A segunda, em 1835, quando Manuel Alves Branco, Ministro dos Negócios Estrangeiros, buscou junto ao Ministro dos Negócios Estrangeiros de Portugal, Sá da Bandeira, autorização para o mesmo fim. Seu pedido, no entanto, foi obstaculizado. A terceira, ocorreu em 1850, às vésperas da promulgação de uma nova lei antitráfico pelo governo brasileiro. Na ocasião Paulino José Soares de Souza, então chanceler brasileiro, mais uma vez enviava requerimento às autoridades competentes da administração do ultramar português solicitando a admissão de agentes consulares brasileiros nos portos da África com base no princípio da reciprocidade entre as nações amigas. A este último pedido, respondeu o governo de Lisboa positivamente, ainda que tardiamente, autorizando, em 17 de março de 1854, o estabelecimento de consulados brasileiros em todos os seus portos ultramarinos abertos ao comércio estrangeiro com as nações amigas de Portugal. 0 que se deu, efetivamente, a 23 de agosto daquele mesmo ano, quando o recém elevado ao Ministério dos Negócios Estrangeiros, José Maria da Silva Paranhos, nomeara Hermenegildo Frederico Niterói para o cargo. Relatórios da Repartição dos Negócios Estrangeiros, 1835, p.5; de 1850, p.4; e de 1856, p.7.

42

COSTA e SILVA, Alberto. Op. Cit., p.32.
Penetrado, como está o governo, de todo o horror, que inspira o bárbaro comércio de carne humana, convencido da gravidade de uma matéria, à qual estão tão intimamente ligados os mais vitais interesses do Império, conciso finalmente dos funestos efeitos, que resultam da violação flagrante das leis, muito deplora o mesmo governo a inutilidade dos seus esforços empregados para a repressão de tão vergonhosas especulações; visto que, ensinando a observação que todos ou quase todos os navios ocupados em tais negociações são pertencentes à nação portuguesa, aos súditos da qual não é proibido o tráfico, se não nos portos do Norte do Equador, como se acha estabelecido em Tratado assinado em 22 de janeiro de 1815, e [em] Convenção Adicional de 28 de julho de 1817 (...) Instruído sobre verdadeira causa do mal, e desejando com ardor por termo à torrente das fraudes e abusos, que todos deploram, o governo imperial não se tem descuidado de chamar a atenção do gabinete de S. M. Fidelissima sobre esta importante matéria, e com quanto nenhum ajuste se tenha ainda concluído entre as duas Coroas, com tudo é de [se] esperar que as negociações encetadas sobre tal assunto, logo que as circunstâncias o permitam, hajam de receber a devida conclusão. ${ }^{39}$

A "devida conclusão" a que Maciel Monteiro se referia era, não outra, que a urgência de uma ação conjunta entre Brasil e Portugal para pôr um fim àquele disparate. Para tanto, não faltaram iniciativas. Isso, ao menos, do lado brasileiro. Pois, antes mesmo que a venda simulada de navios a portugueses viesse a ganhar a proporção de 1836 e de 1838, o governo brasileiro já vinha se empenhando em tentar convencer o governo português da necessidade e da justeza de se abrir um consulado brasileiro naquela que era a terra donde saiam os maiores carregamentos de africanos escravizados rumo ao Brasil, ou seja, em Angola.

Convencido deste propósito, Alves Branco, um dos primeiros ministros a relatar a negativa participação de "embarcações portuguesas" no tráfico atlântico para o Brasil, teimava em oficiar "nos termos mais enérgicos às Cortes de Lisboa" que, para que se alcançassem resultados mais eficazes na supressão do mesmo, era indispensável, além de "um cruzeiro mais vigilante" sobre as colônias portuguesas, que "o governo imperial [fosse autorizado a] nomear um cônsul geral para residir em Angola com o fim de [ali] vigiar sobre o armamento de embarcações de pretos africanos" 4 . Sonho acalentado, "tão logo que viu a sua Independência reconhecida por Lisboa"41, a constante insistência brasileira em instalar um consulado em Luanda acabou por gerar suspeitas, entre alguns setores do Estado português acerca dos motivos reais que levavam o Brasil a reivindicar a abertura de consulados na África, em especial naquele que era o porto por excelência do tráfico atlântico de escravos africanos. Como afirma Costa e Silva:

Temiam as autoridades portuguesas que um cônsul do Brasil em Luanda pudesse, com sua presença ativa, estimular um partido independentista angolano ou os defensores da união com o Império brasileiro, embora estivesse essa última hipótese expressamente proibida no tratado de 29 de agosto de 1825 . Havia ainda o receio de que viesse o cônsul a contribuir para intensificar "a navegação brasileira, ou acobertada pelo pavilhão brasileiro", entre os portos das duas margens do Atlântico Sul. Isso ocorreria em detrimento dos navios de bandeira portuguesa e da política lusitana de reorientar para Portugal o comércio de Angola, que estava, antes da Independência do Brasil, tradicionalmente ligado ao Rio de Janeiro, à Bahia e ao Recife. ${ }^{42}$

Nesse sentido, aos olhos dos estadistas de Portugal, tão real quanto o perigo da perda - ou, caso se prefira, da usurpação - que pairava sobre os territórios na África, era, também, o interesse brasileiro em desestabilizar o domínio colonial português. Disso se explica a relutância com que estes 
43

Com a dissolução do Império luso-brasileiro, em 1822, tornada irrevogável em 1825, os estadistas portugueses voltam sua atenção para os domínios ultramarinos na África. Objetivando estreitar as relações daquelas possessões com a metrópole, logo se entende que o refreamento do tráfico atlântico de escravos entre aquelas e o Brasil é uma das suas principais necessidades. Todavia, pelo menos até a segunda metade do Oitocentos, esses planos de regeneração do Império ultramarino português ainda não se encontravam amadurecidos, o que, por sua vez, contribuiu para a prorrogação das relações mercantis entre os portos da África portuguesa e os do Brasil. ALEXANDRE, Valentim. 0 império português (1825-1890)... Op. Cit., p.959-979.

44

CERVO, Amado \& MAGALHÃES, José Calvet de. Depois das caravelas... Op. Cit., p.140.

45

BETHELL, Leslie. A abolição do tráfico de escravos no Brasil... Op. Cit., p.103. A década de 1820 pode ser apreendida como um momento de relativa calmaria das relações anglo-lusitanas no que tange a questão do tráfico atlântico de escravos. Isso porque, até 1825, a diplomacia britânica esteve direcionada na tarefa de mediar a reconciliação entre Portugal e Brasil após a cisão ocorrida em finais de 1822. Na segunda metade dos anos 20, por conseguinte, esteve a diplomacia da Grã-Bretanha extremamente ocupada em tirar do Brasil uma cláusula proibitiva mais efetiva com relação ao comércio negreiro realizado sob a sua bandeira. Destas circunstâncias resultam a relativa calmaria das relações anglo-lusitanas até o princípio da década de 1830.

46

BETHELL, Leslie. A abolição do tráfico de escravos no Brasil... Op. Cit., p.105-106.

47

ALEXANDRE, Valentim. Portugal e a abolição do tráfico de escravos... Op. Cit., p.301. aceitavam em tratar da implantação de medidas conjuntas entre os dois países para a abolição do tráfico extracontinental de escravos. Assim como - Brasil julgava ser da sua única e inteira responsabilidade a supressão do contrabando da mercadoria humana realizado em seus portos, Portugal considerava dentro das atribuições de sua soberania a regulamentação do comércio escravo levado a cabo por seus súditos e em seus domínios. ${ }^{43}$ Diante deste quadro, não demorou muito para que a questão do embandeiramento, ou seja, a passagem simulada dos navios negreiros brasileiros para o pavilhão português, gerasse alguma animosidade nas relações luso-brasileiras. Denúncias mútuas de complacência das respectivas autoridades nacionais na realização desta prática tornaram-se frequentes nas correspondências diplomáticas trocadas entre os dois paises. ${ }^{44}$ Da mesma forma que, os protestos mútuos de supostas arbitrariedades cometidas no ato da captura de uma ou outra embarcação, fosse pelo trabalho conjunto das forças navais anglo-brasileiras fosse pelo trabalho conjunto das forças navais anglo-lusitanas, tornaram-se corriqueiros.

Estas circunstâncias apenas demonstravam que a cooperação internacional entre Portugal e Brasil, para frear a comercialização da mão de obra escrava pelo Atlântico ou para proporcionar alguma sobrevida extra ao mesmo fito comercial, era muito difícil de articular, praticamente impossivel. A desinteligência entre as expectativas vislumbradas por suas diplomacias a serviço do comércio atlântico de braços de trabalho africanos era total. Tal desconcerto repercutiria na década de 1840, em um trágico e humilhante episódio à soberania primeiramente de Portugal e, posteriormente, do Brasil, manchadas graças a adoção unilateral por parte da Grã-Bretanha dos dois "Bills irmãos" - o Palmerston (de 1839) e o Aberdeen (de 1845) - mais determinados em extinguir absoluta e definitivamente o tráfico de escravos realizado sob as bandeiras lusitana e brasileira.

\section{Liquidados na mesma moeda: o fim do tráfico de Portugal e do Brasil} No que toca exclusivamente o âmbito das relações anglo-lusitanas, "após um intervalo de quase uma década, as negociações (...) para a abolição do tráfico de escravos tornaram-se, uma vez mais, uma das grandes preocupações do governo britânico"45. 0 interesse do governo londrino de retomar as negociações nesse sentido com Portugal manifesta-se em 1834 e (re)surge, como tradicionalmente ocorria nas relações entre as duas nações, a partir da "cobrança" britânica por favores prestados à Coroa portuguesa. Desta vez, mais precisamente, em função do apoio militar durante a guerra civil (1826-1834) para reconduzir D. Maria II ao trono lusitano. Contudo, em vista da inconstância dos gabinetes portugueses no curto período de 1834 e 1836, todas as negociações empreendidas pelo representante britânico em Lisboa, lord Howard de Walden, foram frustradas. ${ }^{46}$ Ainda assim, cabe ressaltar que a instabilidade política vivenciada pelo Portugal na primeira metade da década de 1830 não foi o fator preponderante para o emperramento da ingerência britânica sobre o comércio de escravos português. Mais uma vez, era a diplomacia do tráfico vislumbrada pelos estadistas de Portugal a responsável por tal emperramento. Temerosos em enfrentar as agruras que a abolição do tráfico sob a bandeira portuguesa poderia incorrer para a estabilidade da política ultramarina lusitana, os estadistas portugueses esperavam que uma primeira iniciativa nesse sentido viesse de fora do país, mais precisamente do Brasil. ${ }^{47}$

Fato é que, não havia até então no governo português um projeto ou um estadista realmente disposto em extinguir ou minimamente lidar com 
ALEXANDRE, Valentim. 0 império português (1825-1890)... 0p. Cit., p.962. A preeminência de Sá da Bandeira à frente da política colonial portuguesa do século XIX parece ser realmente um consenso da historiografia portuguesa, tanto da ala mais contemporânea como da ala mais tradicional. Da ala mais contemporânea, além de Alexandre, pode se destacar o trabalho de SARDICA, José Miguel. A Regeneração sob o signo do consenso. A política e os partidos entre 1851 e 1861. Lisboa: ICS-UL, 2001. Já da ala mais tradicional, lista-se, por exemplo, o estudo de CAYOLLA, Lourenço. Sá da Bandeira. Coleção figuras e feitos do além-mar. Lisboa: Agência Geral do Ultramar, 1969.

49

Para maiores informações acerca das minúcias do projeto e do pensamento político de Sá da Bandeira em relação ao tráfico atlântico de escravos ver: ALEXANDRE, Valentim. Portugal e a abolição do tráfico de escravos... Op. Cit. p.304-317.

LAINS, Pedro. 0p. Cit., p.468.
Estas medidas restritivas e punitivas não tiveram, contudo, efeito algum, pois, nos dizeres de Alexandre, "se o governo de Lisboa não tinha mãos nem nos seus cônsules, menos ainda se conseguiria fazer obedecer pelas autoridades coloniais das possessões de África [onde] o peso e a influência política dos interesses locais, jà muito fortes no Antigo Regime [...] cresceram ainda [mais] depois da guerra civil e da vitória dos liberais na metrópole, que, pondo em causa o sistema de administração centrado nos capitães-generais, abria um período de indefinição e por vezes mesmo vazio de poder, preenchido geralmente pela criação de juntas de governo formadas por membros das oligarquias da colônia". ALEXANDRE, Valentim. Portugal e a abolição do tráfico de escravos... 0p. Cit., p.309.

52

BETHELL, Leslie. A abolição do tráfico de escravos no Brasil... Op. Cit., p.109. o comércio negreiro. Foi somente na conjuntura da Revolução Setembrista, de 1836, com a volta dos ultranacionalistas ao controle do governo de Portugal, que essa possibilidade veio, de fato, a ganhar corpo com o surgimento da via nacional para a abolição do tráfico atlântico de escravos, idealizada pelo Visconde de Sá da Bandeira, presidente do Conselho de Ministros do governo português e considerado por muitos historiadores portugueses como "a mais importante personalidade da política colonial portuguesa de todo o século XIX"48. Em linhas gerais o projeto antitráfico de Sá da Bandeira previa o seguinte: $1^{\circ}$. Abolir o tráfico atlântico de escravos entre as possessões portuguesas, excluindo, todavia, o tráfico interiorano do império de qualquer restrição; $2^{\circ}$. Os direitos de visita, busca e apreensão cedidos desde 1817 à Royal Navy seguiriam mantidos, contudo, em face da extinção das comissões mistas anglo-lusitanas, o que, consecutivamente, liberaria as presas para serem julgadas pelos próprios tribunais portugueses; $3^{\circ}$. A decisão do destino dos escravos resgatados permaneceria da mesma forma condicionada ao julgamento dos tribunais portugueses; $\mathrm{e}_{1} 4^{\circ}$. Portugal aceitaria negociar com a Grã-Bretanha a divisão do julgamento dos navios apreendidos, a decisão do destino dos escravos libertados, bem como outras cláusulas a envolver as peças e os equipamentos das embarcações apreendidas desde que, em troca, recebesse garantias dos interesses e da soberania portuguesa em questões de litígio na África. ${ }^{49}$

Segundo Pedro Lains, o projeto de Sá da Bandeira se constituía, na realidade, em um audacioso plano de readequação da histórica influência britânica sobre Portugal, através do qual se almejava renovar as bases do "servilismo português" em prol da defesa dos domínios coloniais remanescentes. Ao fim e ao cabo, ele representava uma tentativa de conciliar os sentimentos anglofóbicos, característicos ao espírito do setembrismo, à realidade precária do Estado ultramarino português..$^{50} \mathrm{Afora}$ isto, percebese ainda que o projeto de Sá da Bandeira não suprimia a diplomacia do tráfico do Estado português. Ao contrário, ele a reafirmava e a reorientava, ao condenar o comércio desenvolvido no ambiente atlântico, ao passo que defendia abertamente a continuidade do comércio negreiro interiorano entre os domínios e possessões lusas na África. Posto nestes termos, é possível inquerir que, por trás dessa reorientação encontrava-se implicitamente colocado o desejo das autoridades portuguesas de ampliar o controle sobre o giro capital de suas colônias, ao suprimir uma atividade mercantil na qual a metrópole historicamente detinha uma posição marginal.

Deste modo, numa tentativa de demonstração da boa vontade portuguesa em cooperar com a Grã-Bretanha na abolição do tráfico atlântico de escravos, desde que respeitadas as propostas levantadas por Sá da Bandeira, o governo lisboeta endereçou, entre dezembro de 1836 e janeiro de 1837, circulares aos seus cônsules e autoridades coloniais informando-os das novas restrições e penalidades que ele promulgara no intento de ao menos limitar aquela que era a prática mais censurada pelo governo de Londres e, como vimos nas páginas anteriores, também pelo governo do Rio de Janeiro: a do embandeiramento ${ }^{51}$. Contudo, resultassem ou não aquelas medidas algum efeito, o governo britânico jamais concordaria com premissas como aquelas, tidas como surpreendentes por Walden e como inadmissiveis por Palmerston, embaixador e Ministro do Foreign Office, respectivamente. ${ }^{52}$ Isto porque, após décadas de negociações e de inúmeras manifestações de "rebeldia" por parte dos sucessivos governantes lusitanos, a Grã-Bretanha, sob a batuta de Palmerston, pa- 
Apresentado a 10 de julho de 1839 à Câmara dos Comuns, o Bill foi ali rapidamente acolhido e aprovado. Talvez, pela proximidade dos interesses dos parlamentares daquela Casa com os interesses coloniais dos cultivadores do Caribe. Na Câmara dos Lordes, entretanto, o Bill encontrou forte oposição do Duque de Wellington, mais afeito à defesa dos direitos internacionais garantidos em tempos de paz, $\mathrm{e}_{\mathrm{i}}$ também à tradicional aliança entre Grã-Bretanha e Portugal. BETHELL, Leslie. A abolição do tráfico de escravos no Brasil... Op. Cit., p.159-163.

56

O Tempo, n.437, 29/07/1839. Apud. ALEXANDRE, Valentim. Portugal e a abolição do tráfico de escravos... Op. Cit., p.319.
O Nacional, n.1368, 31/07/1839. Apud. ALEXANDRE, Valentim. Portugal e a abolição do tráfico de escravos... Op. Cit., p.319. recia cada vez mais inclinada em reavaliar os laços de aliança e amizade que a ligavam a Portugal.

Foi no inverno de 1837-1838 que se operou tal reavaliação. Ali Palmerston finalmente chegou à conclusão de que, no caso de Portugal, melhor do que a diplomacia poderia ser, talvez, o uso da coerção. ${ }^{53}$ Neste sentido, enquanto Walden prosseguiu com as negociações com o gabinete de Sá da Bandeira, Palmerston encaminhou ao Parlamento britânico um Bill de sua autoria no qual, passando por cima do direito internacionalmente consagrado da liberdade dos mares, autorizava os navios britânicos estacionados ao longo da costa atlântico-africana a apresar todas as embarcações sob o pavilhão português entregues ao comércio negreiro e a remetê-las a julgamento nos tribunais do Vice-Almirantado britânico mais próximos. ${ }^{54} \mathrm{~A}$ partir de então, a decisão sobre o controle do tráfico oceânico de escravos feito sob sua bandeira saiu das mãos do governo português. Tudo dependia, agora, da predisposição dos parlamentares britânicos em continuar com as negociações bilaterais anglo-lusitanas, ou em seguir conforme a ação unilateral arquitetada por Palmerston.

Em 24 de agosto de 1839 era, enfim, tomada uma decisão para este impasse. Após ser debatido por quase dois meses na Câmara dos Lordes, o Bill Palmerston tornou-se lei, sendo suas estipulações imediatamente aderidas pelos oficiais da Royal Navy. ${ }^{55}$

A repercussão do Bill em Portugal desencadeou entre os portugueses uma onda anglofóbica que há tempos não se via naquele país. Todas as atenções da imprensa local voltaram-se nas semanas que se seguiram da apresentação até a aprovação final daquele na Câmara britânica, para a cobertura do evento que ali estava sendo considerado como um afrontoso ultimatum à soberania portuguesa. Um dos primeiros artigos nesse sentido pode ser encontrado em uma publicação de 0 Tempo, nas vésperas da apresentação do Bill aos Lordes, na qual se lia:

[...] esta pretensão do governo inglês é altamente atentatória da independência das nações, e sobremaneira agressora contra o seu comércio; porque abriria uma porta ampla, a fim que os ingleses, a pretexto de extinguir o tráfico da escravatura, aniquilassem a navegação dos outros povos e reconcentrassem em suas mãos todo o comércio do Atlântico; mas sem dúvida é contra Portugal que esta tentativa se torna mais prejudicialmente atentatória. ${ }^{56}$

A publicação de 0 Nacional, dois dias depois, fazia coro às palavras da gazeta anterior, evidenciando a homogeneidade dos discursos e das impressões do contexto então vivenciado:

\footnotetext{
É a primeira vez que uma potência estrangeira se arroja o direito de legislar para um povo livre e independente como se este pertencesse ao seu grêmio. (...) o Direito das Gentes foi calcado aos pés por um gabinete que se diz liberal e ilustrado, decretou-se a ruína da nossa navegação, por isso que não queremos conceder aos ingleses direitos da Alfândega privilegiados, por isso que não Ihes cedemos as nossas colônias, e tudo a pretexto de filantropia, de desvelo pelo bem-estar dos africanos, por isso que não temos marinhas para opor à sua. Refalsada [sic] e indignada hipocrisia que os factos [sic] escandalosamente desmentem $!^{57}$
}

O Atleta, não só compartilhava da opinião veiculada nos dias anteriores por seus pares, como conclamava o governo português a empreender alguma forma de retaliação, a fim de salvar, pelo menos, a honra e a dignidade nacional: 
58

O Atleta, n.173, 05/08/1839. Apud. ALEXANDRE, Valentim. Portugal e a abolição do tráfico de escravos... Op. Cit., p.320.

59

ALEXANDRE, Valentim. Portugal e a abolição do tráfico de escravos... Op. Cit., p.321.

60

BETHELL, Leslie. A abolição do tráfico de escravos no Brasil... Op. Cit., p.163.

61

Intervenção de Palmela de 14/07/1840 na Câmara dos Senadores de Portugal. Apud. ALEXANDRE, Valentim. Portugal e a abolição do tráfico de escravos... Op. Cit., p.325.

62

Ibidem.

63

BETHELL, Leslie. A abolição do tráfico de escravos no Brasil... Op. Cit., p.183.

64

Com a revogação do Bill Palmerston os navios sob a bandeira portuguesa deixaram de ser apresados pela Royal Navy em águas territoriais portuguesas. Da mesma forma que deixaram de ser julgados pelos Tribunais do Vice-Almirantado britânico e voltaram a ser apresentados diante das comissões mistas na África. ALEXANDRE Valentim. Portugal e a abolição do tráfico de escravos... Op. Cit., p.326.
[...] o governo português deve continuar em a sustentação da dignidade nacional, já que não tem uma marinha que vá punir quem ousar menosprezar excepcionalmente a nossa bandeira, ponha ao menos em prática tudo quanto tiver ao seu alcance já que o perigo parece inevitável para nossas possessões, não o corra o nosso decoro; diga embora lord Palmerston que nos roubou o que tínhamos de bom - os monumentos da nossa antiga glória; mas não diga ao menos que o Português abaixara o pescoço para receber o jugo inglês - "Perca-se tudo hormis /1 honneur".58

Hormis l'honneur (salve a honra) rapidamente parece ter se convertido numa espécie de palavra de ordem, sendo repetida e massivamente repercutida por todos os periódicos, dos liberais aos mais conservadores. ${ }^{59}$ A possibilidade de Portugal declarar guerra à Grã-Bretanha, aliás, não foi deixada de lado por Palmerston. 0 seu Bill, na realidade, já implicava em um estado de guerra não declarado entre as duas nações. E em correspondência particular a Walden, este ainda revelava grande esperança de ver Portugal tomar essa medida. 0 que, a seus olhos, seria "tanto melhor, pois, várias das suas colônias nos conviriam muito e, tendo-as tomado na guerra, retê-las-íamos na paz que eles nos rogariam de joelhos". ${ }^{60}$ Contudo, enquanto a opinião pública portuguesa, ao menos a noticiada nos periódicos mencionados, parecia aceitar o risco de tudo perder, menos a honra, os seus estadistas demonstravam-se bem mais moderados e indecisos diante do caminho a ser tomado. Ocorre que, se nos idos dos anos de 1830 e princípio dos de 1840, Portugal achava-se em tão ingrata situação, a culpa, nas palavras de D. Pedro de Sousa Holstein, duque de Palmela, devia-se justamente à teimosia obstinada dos próprios portugueses em defender 0 :

[...] tráfico da escravatura, estigmatizado e anatemizado [sic] pelo mundo inteiro, porque ainda que [nós portugueses] digamos que a questão não é a defesa do tráfico (...) este negócio [o Bill Palmerston] provém radicalmente daí [...]. ${ }^{61}$

Ao chamar a atenção dos demais estadistas portugueses para este fato, Palmela rejeitava as duas vias de reação até então levantadas, a da anomalia e a da guerra, e aventava uma terceira via: a da conclusão o quanto antes de um novo convênio anglo-lusitano que viesse a revogar o Bill Palmerston.

Por este novo convênio, os laços de amizade e aliança entre as duas nações deveriam ser renovados, mesmo que à custa de algumas estipulações duras e humilhantes, a exemplo do controle sobre o apresamento e o julgamento das embarcações empregadas no tráfico atlântico de escravos. ${ }^{62}$ Das três vias preconizadas, a de Palmela aparentava ser a menos ruim. Com efeito, nos primeiros anos da década de 1840, o governo lisboeta persistiu incansavelmente no reestabelecimento das negociações com 0 governo londrino. 0 que se deu entre março e julho de 1842, quando Walden e Palmela concordaram em um tratado que "satisfazia o governo britânico em todos os pontos discutidos durante quase uma década, incluindo [as] cláusulas de equipamento e desmontagem" ${ }^{13}$ dos navios negreiros vistoriados e capturados, e que, por outro lado, atendia minimamente na recuperação da honra portuguesa com a revogação do Bill Palmerston e de todas as demais implicações à soberania lusitana por este impostas. ${ }^{64}$

Alguns fatores, um de ordem doméstica da própria Grã-Bretanha, outro de ordem conjuntural atlântica, podem explicar a retomada das boas relações anglo-lusitanas em 1842. Ainda que o Bill Palmerston tenha sido uma medida rude e extremada, na qual uma nação incontavelmente mais 
BETHELL, Leslie. A abolição do tráfico de escravos no Brasil... Op. Cit., p.181-183. poderosa se sobrepôs a outra indistintamente mais fraca, ele havia cumprido com o seu papel e graças a ele a Grã-Bretanha assegurou de uma só vez tudo o que queria para garantir a exclusão da bandeira portuguesa no tráfico atlântico de escravos. Sendo assim, ao preservar os direitos ali conquistados em um novo acordo, não havia necessidade de manter uma atuação tão intensa e lesiva sobre a marinha mercante de Portugal. Os efeitos coercitivos já podiam ser "afrouxados". Ademais, uma mudança ocasional na direção do governo britânico veio a ocorrer em 1841, com a ascensão do duque de Wellington e de lord Aberdeen, aos postos de Primeiro Ministro e de Ministro do Foreign Office, concomitantemente. Conhecidos por suas "simpatias lusitanas", não é estranho que tenham trabalhado no sentido de reatar as "boas falas" de Londres com Lisboa. ${ }^{65}$

Entrementes, também por volta de 1842 , todas as atenções da Grã-Bretanha voltar-se-iam naturalmente de Portugal para o Brasil. A razão disto, em grande parte, deve-se justamente à afirmação deste novo contexto atlântico no qual, até certo ponto, o Brasil passou a configurar como o derradeiro empecilho ao pleno advento do abolicionismo. Ciente, portanto, do retrospecto positivo alcançado nos anos finais da década de 1830 sobre os demais Estados atlânticos, sobretudo depois da experiência coercitiva sobre Portugal, a diplomacia britânica não demorou em procurar emplacar novas negociações com os estadistas brasileiros.

É bem verdade, no entanto, que o governo britânico jamais deixou de tentar empreender com o governo brasileiro novas negociações sobre este fato. Em 1832, Arthur Aston procurou Bento da Silva Lisboa, então ocupante da pasta dos Negócios Estrangeiros do Império, para Ihe propor reformas no tratado antitráfico firmado entre as duas nações em 1826. Na ocasião, apegando-se a lei proibitiva do tráfico atlântico de 1831, que havia sido recentemente promulgada pelo Parlamento brasileiro, Silva Lisboa conseguiu esquivar-se de entrar em novas conversações nesse sentido com o enviado britânico.

Entre 1834 e 1835, durante a gestão subsequente no mesmo Ministério de Aureliano de Sousa Oliveira Coutinho e de Manuel Alves Branco, os respectivos substitutos de Aston na Corte carioca, William Gore Ouseley e Henry Stephen Fox, aventuraram-se sem maiores sucessos na mesma missão. Este último, aliás, embora tenha entrado em acordo com Alves Branco para a inclusão de artigos adicionais às Instruções que regulamentavam os trabalhos das comissões mistas anglo-brasileiras criadas para julgar as presas suspeitas de traficarem, viu seu trabalho emperrar na Comissão de Constituição e Diplomacia da Câmara. Ali arquivado, o acordo Fox-Alves Branco só foi relembrado anos mais tarde, mais precisamente em 1837, após muita insistência de Hamilton para que Francisco Gê Acaiaba de Montezuma, então atual ocupante da chancelaria brasileira, submetesse de uma vez a questão ao Parlamento. Ainda assim, os esforços de Hamilton foram mais uma vez frustrados, dessa vez em decorrência da mudança brusca na direção do governo brasileiro em setembro daquele ano, quando um novo gabinete, organicamente vinculado aos interesses escravocratas, conseguiu, mais uma vez, evitar a retomada da discussão do acordo na Comissão.

Em face destas informações, podemos afirmar que, ao longo da década de 1830, o Brasil ofereceu igual ou maior resistência que Portugal à intromissão britânica no tráfico realizado abaixo de sua bandeira. Ainda assim, o tratamento dispensado por Londres em suas negociações com Lisboa e Rio de Janeiro no mesmo período é adverso. Enquanto que 
Ibidem, p.115. LAINS, Pedro. Op. Cit., p.475. ALEXANDRE, Valentim. Portugal e a abolição do tráfico de escravos... 0p. Cit., p.299

67

BETHELL, Leslie; CARVALHO, José Murilo de. 0 Brasil da independência a meados do século XIX. In: BETHEL, Leslie (Org.). História da América Latina. Op. Cit., Vol.IIl, p.695-769 (citação literal da página 746)

68

É certo que as acusações de favorecimento à causa britânica contribuíram no desgaste da imagem pública de Oliveira Coutinho. Todavia, deve-se destacar o fato de que boa parte destas acusações eram, na realidade, fomentadas pelos traficantes, que "manipulavam habilmente os sentimentos nacionalistas da população para conduzir a opinião pública em apoio de seus interesses ameaçados". Ademais, outra parte do desgaste pessoal de Aureliano, deve-se às intrigas e manobras golpistas do próprio ambiente palaciano de princípio dos anos quarenta, movidas pelo Clube da Joana do Mordomo-Mor do imperador Paulo Barbosa da Silva e pelo Partido da Imperatriz de Honório Hermeto. Para uma leitura mais completa do cenário político da primeira década do Segundo Reinado ver CASTRO, Paulo Pereira de. Política e administração de 1840 a 1848. In: HOLANDA, Sérgio Buarque de (Org.). Op. Cit. Vol.II - Dispersão e unidade. p.509-540. com o primeiro assisti-se a um endurecimento paulatino, com o segundo verifica-se ainda certa "complacência". Na opinião de alguns autores, entre os quais se destacam Bethell, Lains e Valentim ${ }^{66}$, isso se deve porque, nos anos de 1830, dado o crescimento da prática do embandeiramento sob o pavilhão português somado aos desejos britânicos de obter 0 controle informal do maior número de mercados africanos e de manter a primazia comercial sobre o mercado brasileiro, era mais proveitoso à Grã-Bretanha endurecer, naquele momento, com Lisboa do que com o Rio de Janeiro. Solucionada, porém, a face portuguesa do tráfico intercontinental de africanos, não tardou para que a diplomacia britânica iniciasse, agora mais enfaticamente, as tratativas no intuito de reabrir os canais de negociação com o Brasil.

De 1841 a 1843, pouco depois da antecipação da maioridade de Pedro II, coube a Aureliano de Sousa a chefia do Conselho dos Ministros. Conhecido entre os diplomatas britânicos por sua postura liberal e por sua cooperação em prol da repressão do tráfico atlântico de escravos quando de sua primeira passagem pela Repartição dos Negócios Estrangeiros (1833-1834), a chefia ministerial de Aureliano de Souza foi bem recebida por lord Aberdeen, que desejando aproveitar os "bons ventos liberais" que então sopravam sobre o Brasil, nomeara Henry Ellis como novo embaixador de Sua Majestade Britânica junto à Sua Majestade Imperial.

Instalado na Corte de São Cristóvão em fins de 1842, a Missão Ellis tinha múltiplas e delicadas tarefas. Ainda assim, era de conhecimento comum que, entre seus principais objetivos, constava o início das conversações em torno da renovação das cláusulas comerciais previstas no tratado anglo-brasileiro de 1827, que favoreciam as manufaturas britânicas; bem como, persuadir o governo brasileiro em aceitar as medidas necessárias para assegurar a abolição plena da importação de novos cativos saídos da África num curto espaço de tempo. Contudo, tão logo chegou ao Rio de Janeiro, Ellis se deparou com um ambiente extremamente hostil, tanto por parte da imprensa e da opinião pública brasileira, como por parte do novo gabinete encabeçado por Honório Hermeto Carneiro Leão, ironicamente empossado logo depois de sua chegada. Recusando-se a entrar na delicada questão do comércio negreiro, a qual julgava ser uma questão a ser pensada no futuro e não no presente ${ }^{67}$. Carneiro Leão também não demorou em interromper as negociações.

A historiografia tem identificado na obstinação de Carneiro Leão em postergar as negociações com a Grã-Bretanha, razões para sustentar a tese de que o fracasso da Missão Ellis seria um resultado direto da mudança brusca na direção nacional, com a queda de Aureliano de Souza. Queda esta, aliás, segundo muitos acreditam, favorecida pelo aumento da impopularidade do próprio Aureliano de Souza, acusado de favorecer os interesses britânicos. ${ }^{68}$ Porém, analisando os Relatórios dos respectivos Ministros, não encontramos bases plausíveis que sustentem nem uma postura anglofílica do liberal Aureliano de Souza nem uma postura anglofóbica do conservador Carneiro Leão. Deparamo-nos, sim, em ambos os casos, com uma política de contemporização, pensada com vista a dar respaldo à postura diplomática do Brasil em relação à campanha internacional abolicionista. Empreendida com afinco pelos subsequentes ocupantes da Repartição dos Negócios Estrangeiros do Império, sobretudo nos tempos da Regência, a política de contemporização, em outras palavras, de acomodação de interesses por natureza conflitantes, tinha a dura missão de entreter os abolicionistas bri- 
69

Relatório da Repartição dos Negócios Estrangeiros, 1843, p.5.

Relatório da Repartição dos Negócios Estrangeiros, 1842, p.12.

Até o final da década de 1830, a esquadra imensamente superior da costa africana e a proeminência dos comissários britânicos na Comissão Mista anglo-brasileira de Serra Leoa faziam com que a Condenação das embarcações ali apresadas fosse quase tão certa quanto em qualquer tribunal do Vice-Almirantado. No que toca a esquadra britânica estacionada na costa brasileira, entretanto, o número reduzido de suas forças e a proeminência dos comissários brasileiros na Comissão Mista anglo-brasileira do Rio de Janeiro, fazia da absolvição dos navios ali capturados quase uma certeza. BETHELL, Leslie. $A$ abolição do tráfico de escravos no Brasil... Op. Cit., p.176-206. tânicos, ao passo que acalentava as expectativas da "boa gente" da sociedade escravista brasileira - entre os quais, vale ressaltar, figuravam muitos traficantes. Era, em sintese, portanto, uma política com vistas a ganhar tempo, da qual tanto Aureliano de Souza quanto Carneiro Leão eram, como nos dão conta os seus Relatórios, seus mais devotados adeptos.

No Relatório de Carneiro Leão, tal postura é apresentada logo na sequência de suas falas, onde o Ministro busca esclarecer ao enviado britânico que a interrupção das negociações de maneira alguma significava o seu completo abandono:

[...] Antes porém que ele (o embaixador Ellis) partisse, tive ocasião de assegurá-lo oficialmente de que S. M. o imperador, desejando apertar cada vez mais os laços de amizade, que o ligam a S. M. a rainha da Grã-Bretanha, enviaria, com a possivel brevidade, um plenipotenciário em missão especial a Londres, para prosseguir na negociação encetada nesta Corte. A nomeação para essa missão foi logo feita, e recaiu na pessoa do conselheiro José Araújo Ribeiro [...]. ${ }^{69}$

Já no Relatório de Aureliano de Souza, a contemporização é predominante no que diz respeito às negociações em prol dos Artigos Adicionais à Convenção anglo-brasileira de 1826:

Tendo a Legação de S. M. Britânica nesta Corte, depois da declaração da maioridade de S. M. o imperador, insistido para que fossem ratificados os Artigos Adicionais à Convenção de 23 de novembro de 1826, assinados em 27 de julho de 1835 por plenipotenciários das duas nações (Fox e Alves Branco), e que então haviam sido remetidos à Câmara dos Srs. Deputados, o governo imperial depois de várias observações sobre os ditos Artigos, não julgou conveniente ratificá-los, e espera que nas razões, que o moveram, verá o governo de S. M. Britânica no do Brasil, a par do desejo de contribuir por todos os modos possiveis para a abolição de um tráfico desumano, e impolítico, o dever de evitar que o comércio lícito dos súditos do Império seja oprimido, e vexado por disposições, das quais, posto que justas quanto ao seu fim, seria muito fácil o abusar-se (...) 0 governo imperial, conciso de seus deveres, e dos seus próprios princípios, não deixará jamais de empregar todos os meios ao seu alcance para conseguir a completa abolição do tráfico de africanos; mas fazê-lo-a sempre dentro da órbita dos compromissos, que para isso contraiu; e marchará neste grave assunto com a circunspeção, que exigem as circunstâncias peculiares do pais. ${ }^{70}$

Analisadas as palavras de Aureliano de Souza, pode-se perfeitamente notar que, embora este condene o tráfico atlântico de escravos, o qual reconhece ser um comércio desumano e impolítico para aqueles tempos, ele não apresenta nenhuma intenção do governo imperial de implantar medidas impopulares que viessem a ter algum efeito direto sobre o mesmo. De modo semelhante, o Ministro ainda assegura ao representante britânico a disposição de seu governo em cooperar, dentro do possivel, para o alcance das pretensões abolicionistas buscadas pela Grã-Bretanha, promessa esta, no entanto, que deveria soar mais de alento do que de real determinação aos ouvidos do britânico.

Fosse como fosse, na transição da década de 1830 para a de 1840, esta política de contemporização já dava sinais de desgaste. Afinal, se até o fim da primeira era flagrante o descompasso da atuação de patrulhamento e de repressão ao contrabando de escravos empreendidos pela Royal Navy entre as costas africana e brasileira ${ }^{71}$, na segunda, mormente após a promulgação e a implantação das medidas previstas pelo Bill Palmerston contra os navios negreiros sob a bandeira portuguesa, assistiu-se a equipa- 
Relatório da Repartição dos Negócios Estrangeiros, 1840, p.7-8.

73

Relatório da Repartição dos Negócios Estrangeiros, 1841, p.5-7.
BETHELL, Leslie \& CARVALHO, José Murilo de. 0 Brasil da independência a meados do século XIX... Op. Cit., p.746.
75

Relatório da Repartição dos Negócios

Estrangeiros, 1844, p.14-15. ração gradual dos atos utilizados pelas forças navais britânicas estacionadas de um lado e de outro do Atlântico.

No Relatório de maio de 1840, apresentado por Caetano Maria Lopes Gama, último Ministro dos Negócios Estrangeiros da Regência de feições conservadora de Pedro Araújo Lima, já encontramos menções da violação da neutralidade brasileira na contenda anglo-lusitana, sendo navios portugueses apresados em águas territoriais brasileiras e encaminhados para as estações britânicas ao longo da costa do Império. ${ }^{72}$ De forma semelhante, no Relatório subsequente de 1841, assinado por Aureliano de Souza, que pela segunda vez ocupava aquela pasta (1840-1842), constatamos não só a continuidade como a acentuação destas violações. 0 que resultou em reclamações "constante, e competentemente [empregadas] (...) do governo de S. M. o imperador ao governo de S. M. Britânica", do qual, tendo em vista "o espírito de justiça, e moderação, que preside ao atual gabinete", esperava o Ministro brasileiro que fossem "dadas aos cruzadores nas costas do Brasil instruções assaz claras, e explícitas, para que cessassem os abusos contra [os quais] se há reclamado".73

0 medo era de que o Bill contra Portugal se voltasse contra o Brasil. Motivos para tanto não faltavam. Ao regressar para Londres, Ellis levou consigo recusas do governo brasileiro em conceder as mudanças desejadas pela Grã-Bretanha na legislação que regulamentava os trabalhos das comissões mistas de ambas as nações, além, é claro, de informações quanto aos impasses apresentados pelo mesmo governo para que fossem renovados os privilégios jurídicos e alfandegários desfrutados pelos súditos e comerciantes britânicos residentes e/ou atuantes no Brasil. Levou também notícias atualizadas e reveladoras que podem ter contribuido para a decisão, pouco tempo depois efetivada, do governo londrino de adotar medidas semelhantes contra o tráfico atlântico realizado por embarcações brasileiras como as que foram usadas contra o tráfico atlântico efetivado pelas embarcações portuguesas entre 1839 e 1842.

\section{[...] Ellis descobriu, para a sua surpresa, que [os comerciantes britânicos estabelecidos no Rio de Janeiro] já não davam tanta importância nem a seus privilégios jurídicos no Brasil nem à tarifa preferencial de 15 por cento; isso tinha sido útil no passado, quando a Inglaterra estava firmando sua posição no mercado brasileiro, mas, desde que não houvesse uma discriminação real contra os produtos ingleses, a superioridade econômica da Inglaterra sobre seus rivais mais próximos garantiria a continuação da predominância inglesa no Brasil [.... ${ }^{74}$}

A partir disto, não é difícil presumir que, uma vez reduzida a necessidade primária de proteger os interesses mercantis britânicos no Brasil, as vozes contrárias ao comércio brasileiro de escravos ganhariam reforços para exigir com mais propriedade do governo britânico a adoção de medidas mais ríspidas e eficazes contra o mesmo. Os casos de apreensão da barca Maria Thereza, pelo Captor, e do brigue Relâmpago, pelo Dolphin, citados pelo Ministro dos Negócios Estrangeiros, Ernesto Ferreira França, em seu Relatório de 1844, mostram que tal realidade, se ainda não havia sido oficialmente empregada, encontrava-se na iminência de vir a sê-lo. Ainda que nelas não tenham sido encontrados escravos, os navios responsáveis pela captura julgaram a ausência dos documentos um indício da realização do tráfico atlântico e incorreram em submetê-las ao julgamento de um tribunal do Vice-Almirantado britânico. ${ }^{75}$ Estes dois episódios, descritos por Ferreira França como uma "violação manifesta das Convenções existentes 
77

Segundo as estimativas em posse do Foreign Office, de 1837 a 1844, 211.626 escravos haviam sido introduzidos no Brasil, contra apenas 7.947 introduzidos no período de 1831 a 1836. BETHELL, Leslie. Apêndice: estimativa da importação de escravos para o Brasil, 1831-1855. In: A abolição do tráfico de escravos no Brasil... Op. Cit., p.368.

78

Uma cópia desta notificação foi anexada ao Relatório de 1846, do Ministro Bento da Silva Lisboa, Barão de Cairu. Relatório da Repartição dos Negócios Estrangeiros, 1846. Notas em nome do governo brasileiro, Anexo №1.

79

BETHELL, Leslie \& CARVALHO, José Murilo de. 0 Brasil da independência a meados do século XIX... Op. Cit., p.756. sobre o comércio da escravatura, senão também uma grave ofensa à dignidade nacional"76, servem, pois, de prenúncio do que ainda estava por vir: 0 Bill Aberdeen.

Promulgado em 8 de agosto de 1845, o Bill Aberdeen reeditava as medidas repressivas anteriormente adotadas contra Portugal pelo Bill Palmerston. Respaldado pelo artigo $1^{\circ}$ do tratado anglo-brasileiro de 1826 , que considerava o comércio negreiro realizado por súditos e/ou por embarcações brasileiras como pirataria, o Bill autorizou os navios da Royal Navy estacionados na extensão de todo o Atlântico Sul a tratar os navios negreiros brasileiros como navios piratas, logo, isentos de proteção de qualquer lei extranacional. Se por um lado o Bill foi uma resposta do gabinete do Primeiro Ministro Peel aos ataques que ele e sua equipe de governo, entre os quais o lord Aberdeen, vinham recebendo desde meados de $1842 \mathrm{em}$ face do recrudescimento do tráfico de africanos para o Brasil ${ }^{77}$, por outro, foi, acima de tudo, uma resposta de força movida pelo governo londrino contra o governo carioca que, em março de 1845, dirigiu ao enviado extraordinário da Grã-Bretanha no Brasil, Hamilton-Hamilton, uma notificação dando conta da cessão de cláusulas significativas à repressão previstas na convenção antitráfico de 1826. Como lembrava o ministro brasileiro ao plenipotenciário britânico:

\footnotetext{
Completando-se amanhã, 13 do corrente mês de março de 1845, os quinze anos durante os quais, segundo as Convenções entre o Brasil e a Grã-Bretanha sobre a abolição do tráfico da escravatura, continuava ainda em vigor a Convenção de 28 de julho de 1817; cessando por conseguinte desde esse dia o direito de visita e de busca e todas as outras estipulações contidas na referida Convenção de (...) 1817, artigos adicionais, instruções e regulamentos anexos (...) [bem como] as comissões mistas brasileiras e inglesas, estabelecidas nesta Corte e em Serra Leoa, [as quais o governo imperial permitirá que] continuem ainda por seis meses (...) para o único fim de concluírem os julgamentos dos casos pendentes, e daquelas que por ventura tenham ocorrido até o referido dia 13 de março do corrente ano. ${ }^{78}$
}

Ao optarem por esta forma de atuação, os estadistas brasileiros esperavam talvez proporcionar uma segunda sobrevida para o comércio de almas. Ao passo que, cassados os direitos de visita, busca e apreensão anteriormente cedidos à Royal Navy, caberia ao governo britânico buscar reavê-los a partir de uma nova rodada de negociação. Contudo, a atitude brasileira foi interpretada pelo governo britânico como uma pressão descabida, uma vez que se originava "de um Estado fraco e outrora dependente"79 que, agora, parecia querer ditar à maior potência dos mares a forma como esta deveria agir no desenvolvimento de sua campanha internacional contra o contrabando de mão de obra escrava. Em suma, um insulto ao orgulho britânico e um absurdo dentro da nova conjuntura, na qual, à exceção do Brasil, nenhum outro Estado do sistema atlântico ousava mais desafiar a política britânica proibitiva de importação de braços de trabalho dos sertões escravistas da África.

\section{À guisa de conclusão}

Este texto não ingressará na discussão acerca da recepção e das consequências do Bill Aberdeen à ordem escravista brasileira, por duas razões: $1^{\circ}$. o quinquênio de 1845 a 1850 é, quiçá, um dos períodos mais rememorados da história brasileira. Nesse sentido, muito já foi - e ainda é escrito, difundido e revisto sobre os eventos que compõem a base deste 
80

Publicado originalmente na língua inglesa, em 1970, pela Cambridge University Press, o livro de Bethell veio a ter sua primeira publicação em português já em 1976, pela Expressão Cultural em parceria com a Editora da Universidade de São Paulo. 0 curto periodo entre a edição inglesa e a edição brasileira atesta o interesse despertado entre os historiadores do lado de cá pelo estudo do historiador inglês.

81

Ao lado do trabalho do historiador norteamericano Alan k. Manchester, Preeminência inglesa no Brasil (1933), editado em português pela Editora Brasiliense, em 1973, e do trabalho do brasileiro José Honório Rodrigues, Brasil e África... Op. Cit., publicado pela primeira vez em 1961, pela Civilização Brasileira, e editado em inglês, já em 1965, pela University of California Press em parceria com Cambridge University Press.

82

Cf. BETHELL, Leslie. A abolição do tráfico de escravos no Brasil... Op. Cit., p.9.

83

A expressão surgiu entre as décadas de 1960 e de 1970 para identificar o grupo de pesquisadores estrangeiros que então fazia da história do Brasil o seu campo de estudo. Para maiores informações ver o dossiê História e Ciências Sociais da revista Estudos Históricos (v.3, n.5, de 1990). período - o Bill de lord Aberdeen e a Lei Eusébio de Queirós; $2^{\circ}$. porque entendemos que o texto já atendeu a sua finalidade que é a de elucidar algumas possibilidades de investigação sobre o enquadramento luso-brasileiro na questão do contrabando de africanos entre as décadas de 30 e 40 do Oitocentos. Desta forma, talvez o que reste ainda para discorrer sejam algumas linhas que expliquem a origem de nossa preocupação com relação à temática aqui apresentada.

Mais do que um recurso de retórica, a nomeação do título deste texto foi pensada no sentido de informar ao leitor, já no seu enunciado, a fonte de origem - do ponto de vista analítico e interpretativo - na qual este ensaio procurou beber e apropriar-se. A saber, A abolição do tráfico de escravos no Brasil: A Grã-Bretanha, o Brasil e a questão do tráfico de escravos, do historiador inglês Leslie Bethell. ${ }^{80}$ Nesta obra, que é talvez uma das mais visitadas pela historiografia nacional e internacional, sobre as implicações políticas profundas que a supressão do comércio negreiro causou ao enquadramento anglo-brasileiro ${ }^{81}$, o grande mérito de Bethell foi expor com maestria o fato de que mesmo sendo o Brasil do século XIX um Estado periférico inserido na zona de influência da Grã-Bretanha, este manejou todas as armas e artifícios políticos de que dispunha para resistir à abrupta ingerência britânica em sua prerrogativa soberana de legislar sobre o tráfico atlântico de escravos realizado sob a sua bandeira.

Segundo Bethell, o grande trunfo do Brasil para equilibrar a balança política com a Grã-Bretanha não foi outro além da negociação. Afinal de contas, foram as respectivas recusas brasileiras em atender de uma só vez a todas as exigências britânicas relacionadas à proibição do tráfico, assim como as divergentes leituras apresentadas por seus representantes acerca de artigos chaves dos tratados e convenções bilaterais celebrados em relação à mesma questão, que permitiram ao país protelar o desfecho da questão do contrabando negreiro por quase vinte anos. 0 autor conseguiu chegar a esta conclusão posto que, como ele próprio assinalou no prefácio de seu trabalho, "embora os esforços britânicos no sentido de abolir o tráfico de escravos tenham chamado por força o melhor de minha atenção, procurei encarar o problema do tráfico de escravos também do ponto de vista brasileira". Ao assim desenvolvê-lo, Bethell deixava clara a sua esperança de que seu livro configurasse "não só uma contribuição para a história da Grã-Bretanha como também para a do Brasil". ${ }^{2}$

A julgar pelo fato, grosso modo, de que os estudos históricos produzidos no Brasil, mormente a partir da década de 1980, muito se inspiraram nas novas frentes de trabalho introduzidas no cenário da historiografia brasileira por análises desenvolvidas há alguns anos ou mesmo há algumas décadas anteriores pelos chamados brasilianistas ${ }^{83} \mathrm{e}$; a contar pela grande aceitação e assimilação que a obra de Bethell recebeu - e segue recebendo - dos historiadores brasileiros interessados na história por trás da declaração de ilegalidade e da abolição definitiva do tráfico negreiro para o Brasil, podemos concluir que o livro atingiu o seu objetivo.

Mas o Brasil não estava sozinho neste cenário. A seu lado estava também Portugal, país cuja questão abolicionista da importação de africanos gerou problemas de igual ou maior monta que no Brasil. Ciente de tal situação, Bethell esta certo ao dizer que, "em termos mais modestos" o seu trabalho

(...) é também uma contribuição à história de Portugal, já que até 1822 o Brasil foi colônia portuguesa e, durante a década de 1830, o tráfico ilegal de escravos para o 
Cf. BETHELL, Leslie. A abolição do tráfico de escravos no Brasil... Op. Cit., p.9.

85 Ibidem.
Brasil continuou a fazer-se sob a bandeira portuguesa, sendo a África Portuguesa até o fim, a maior fonte de escravos para o Brasil (...). ${ }^{84}$

Com efeito, "ainda que o estudo das relações anglo-brasileiras dominadas - e prejudicadas - pela questão do tráfico nos trinta anos que se seguiram à independência do Brasil"85 constitua o cerne do trabalho de Bethell, o estudo da forma com que as relações anglo-lusitanas foram reajustadas em face da mesma questão no mesmo periodo compõe uma parcela significativa do esforço investigativo do historiador inglês. Assim se verifica, por exemplo, quando o autor retrocede aos "Primeiros passos para a abolição", entre 1807 e 1822 (capítulo 1) e, em seguida, retoma as discussões que coligavam o reconhecimento da "Independência [à] abolição" do tráfico brasileiro (capítulo 2) na década de 1820. Nestas passagens, ao tentar compreender de que maneira o tráfico de escravos, um dos pilares da economia brasileira, conseguiu ser declarado ilegal, Bethell não abordou somente os inconvenientes e as relutâncias em fazê-lo dos representantes brasileiros que sentaram para negociar com os emissários britânicos. As implicações e as objeções apresentadas pelos enviados e estadistas portugueses também foram levadas em conta. De forma semelhante, mesmo quando ele se voltou às vicissitudes que mantinham ligados "O Brasil e o tráfico de escravos" já declarado ilegal (capitulo 3), de modo a tornarem impossível a supressão imediata deste último e, inclusive, de prolongar-lhe a existência por mais duas décadas, Bethell recorrentemente fez questão de lembrar que Portugal também tinha os seus vínculos com o comércio escravagista e que pouco fez a princípio para encerrá-los. Na sua visão, eram países identicamente dependentes e defensores do mesmo "infame comércio" o qual só aceitaram extinguir, de fato, diante "A ampliação dos poderes britânicos" de fiscalização sobre o Atlântico Sul, em finais dos anos 30 e princípio dos anos 40 (capitulo 6) e, perante as "Consequências da Lei Aberdeen" de um lado (capitulos 9 e 10) e da Lei Palmerston de outro (capítulo 7).

Posto nestes termos, não surpreende se um levantamento mais apurado da historiografia portuguesa contemporânea interessada na abolição do tráfico de escravo sinalizar que, assim como em terras brasileiras, o livro de Leslie Bethell também alcançou grande repercussão em terras lusitanas.

Para além deste quadro, no entanto, o trabalho de Bethell apresenta, ainda que implicitamente, uma ideia valiosa para a compreensão da história da abolição do tráfico de escravos no Atlântico Sul. Ao pretender investigar o quanto as relações anglo-brasileiras - e, paralelamente, as relações anglo-lusitanas -, da primeira metade do século XIX, teriam sido dominadas e desgastadas pela questão do tráfico negreiro, o historiador tangenciou um aspecto peculiar até então obscuro da fase derradeira do comércio de escravos: o do enquadramento luso-brasileiro no interior da campanha internacional pela sua abolição. A questão do contrabando de africanos inseriu profundas implicações no relacionamento luso-brasileiro Oitocentista, cuja história ainda carece de maiores atenções. Neste sentido, as perguntas, bem como as suas soluções que foram apresentadas ao longo do artigo, devem ser tomadas como sugestões iniciais para futuras pesquisas, posto que, dada a amplitude e complexidade do tema, o assunto merece um trabalho de maior fôlego capaz de aprofundar-se na forma com que Brasil e Portugal lidaram com as pressões vindas da Grã-Bretanha, na maneira como ambos se relacionaram frente a esta questão e, no modo que o destino do tráfico realizado por uma das partes veio a repercutir no destino do tráfico realizado pela outra. 